OPEN ACCESS

UWS Academic Portal

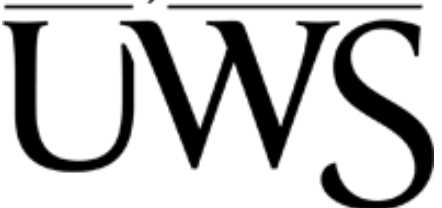

\title{
Design of top-hat purlins for cold-formed steel portal frames
}

Uzzaman, Asraf; Wrzesien, Andrzej; Lim, James B.P.; Hamilton, Robert; Nash, David

Published in:

Structures

DOI:

10.1016/j.istruc.2016.06.006

Published: 01/08/2016

Document Version

Peer reviewed version

Link to publication on the UWS Academic Portal

Citation for published version (APA):

Uzzaman, A., Wrzesien, A., Lim, J. B. P., Hamilton, R., \& Nash, D. (2016). Design of top-hat purlins for coldformed steel portal frames. Structures, $7,113-125$. https://doi.org/10.1016/j.istruc.2016.06.006

\section{General rights}

Copyright and moral rights for the publications made accessible in the UWS Academic Portal are retained by the authors and/or other copyright owners and it is a condition of accessing publications that users recognise and abide by the legal requirements associated with these rights.

Take down policy

If you believe that this document breaches copyright please contact pure@uws.ac.uk providing details, and we will remove access to the work immediately and investigate your claim. 
OPEN ACCESS

UWS Academic Portal

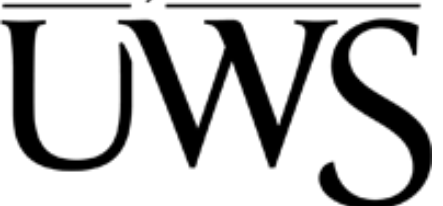

\section{Design of Top-hat Purlins for Cold-formed Steel Portal Frames}

Uzzaman, Asraf; Wrzesien, Andrzej; Lim, James B.P.; Hamilton, Robert; Nash, David

Published in:

Structures

DOI:

10.1016/j.istruc.2016.06.006

Published: 01/01/2016

Document Version

Peer reviewed version

Link to publication on the UWS Academic Portal

Citation for published version (APA):

Uzzaman, A., Wrzesien, A., Lim, J. B. P., Hamilton, R., \& Nash, D. (2016). Design of Top-hat Purlins for Coldformed Steel Portal Frames. Structures, 7, 113-125. https://doi.org/10.1016/j.istruc.2016.06.006

\section{General rights}

Copyright and moral rights for the publications made accessible in the UWS Academic Portal are retained by the authors and/or other copyright owners and it is a condition of accessing publications that users recognise and abide by the legal requirements associated with these rights. 


\title{
DESIGN OF TOP-HAT PURLINS FOR COLD-FORMED STEEL PORTAL FRAMES
}

\author{
Asraf Uzzaman', Andrzej M. Wrzesien ${ }^{\mathrm{b}}$, James B.P. Lim ${ }^{\mathrm{c}}$, \\ Robert Hamilton ${ }^{\mathrm{a}}$ and David Nash ${ }^{\mathrm{a}}$ \\ a Department of Mechanical and Aerospace Engineering, The University of Strathclyde, 75 Montrose Street, Glasgow G1 1XJ \\ b Department of Civil Engineering, The University of Strathclyde, 75 Montrose Street, Glasgow G1 1XJ \\ c Civil \& Environmental Engineering, The University of Auckland, 20 Symonds Street, Auckland, New Zealand
}

\begin{abstract}
This paper considers the use of cold-formed steel top-hat sections for purlins in the UK, as an alternative to conventional zed-sections. The use of such top-hat sections could be viable for cold-formed steel portal framing systems, where both the frame spacing and purlin span may be smaller than that of conventional hotrolled steel portal frames. Furthermore, such sections are torsionally stiffer than zedsections, and so have a greater resistance to lateral-torsional buckling. They also do not require the installation of anti-sag rods. The paper describes a combination of full-scale laboratory tests and non-linear elasto plastic finite element analyses. The results of twenty-seven tests on four different top-hat sections are presented. In terms of stiffness, good agreement between the experimental and finite element results is shown. The finite element model is then used for a parametric study to investigate the effect of different thicknesses and steel grades. Design recommendations are provided in the form of charts. The use of the finite element method in this way exploits modern computational techniques for an otherwise difficult structural design problem and reduces the need for an expensive and time consuming full laboratory study, whilst maintaining realistic and safe coverage of the important structural design issues.
\end{abstract}


Keywords: Cold-formed steel, Purlins, Top-hat sections, Eurocode 3, Finite element analysis

\section{Notation}

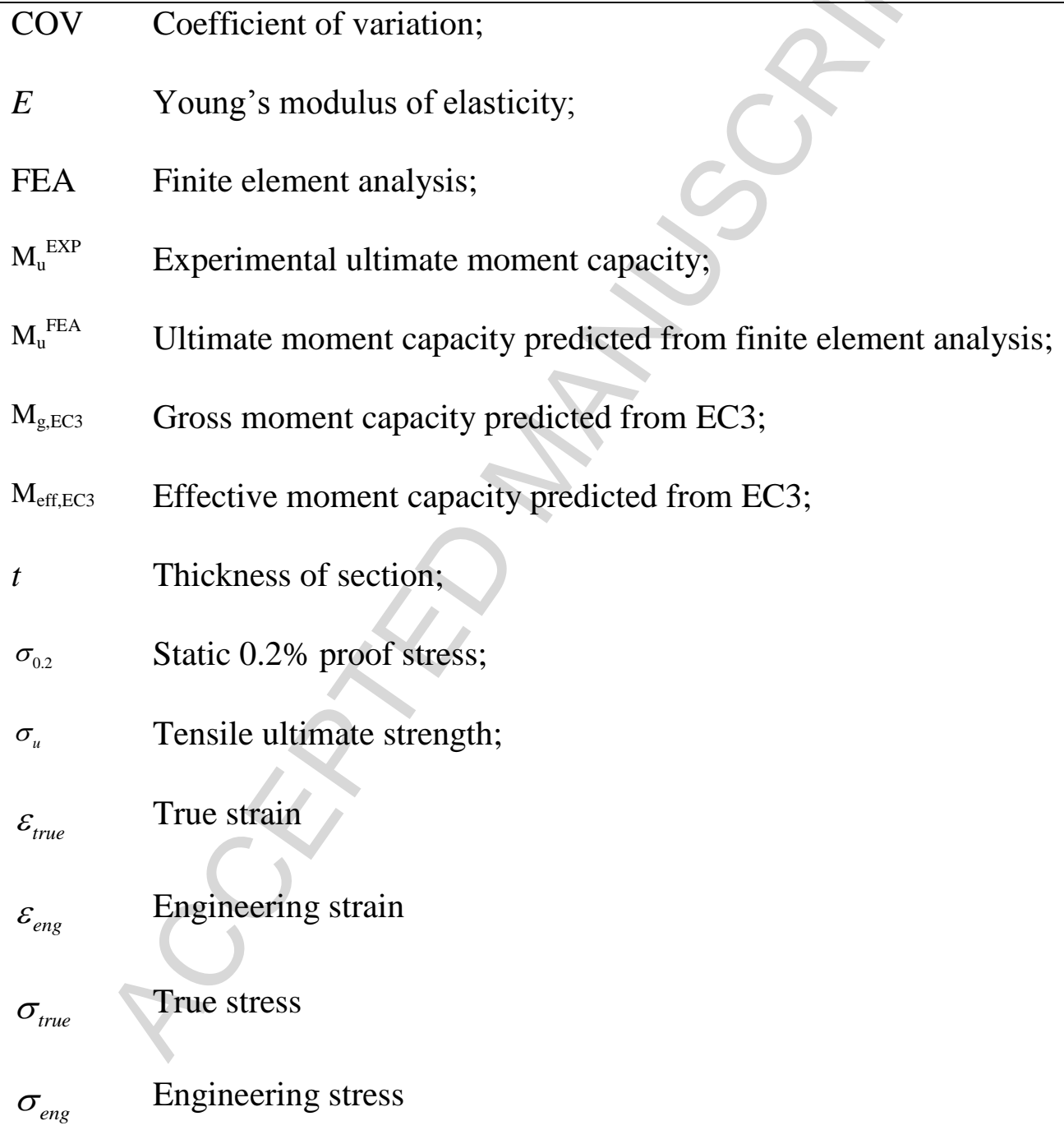




\section{Introduction}

In the UK, single-storey steel portal frames account for approximately $50 \%$ of the constructional steel used each year and $90 \%$ of all single-storey buildings $[1,2]$. Such buildings typically use conventional hot-rolled steel sections for the primary column and rafter framing members, which in turn support the secondary coldformed steel purlin and side rail members; these secondary members, in turn, support the cladding.

For portal frames of modest span (around $12 \mathrm{~m}$ ), the introduction of higher strength grades of cold-formed steel into the UK in the past decade, has led to coldformed steel sections being used for the both primary members as well as for the secondary members (see Fig. 1). Such cold-formed steel portal framing systems are now a viable alternative to conventional hot-rolled steel portal framing systems [3].

However, unlike conventional hot-rolled steel portal frames in the UK, where the frame spacing is typically $6 \mathrm{~m}$, there is scope to vary the frame spacing in the design of cold-formed steel portal frames. This is because cold-formed steel sections are lighter than hot-rolled steel sections, so structural members can be bolted and erected on site by semi-skilled workers, without the need for an onsite crane; consequently, erection costs are much lower than in hot-rolled steel portal frames. A design optimization described by Phan et al. $[4,5]$ demonstrated that topology can have a significant effect on minimizing the cost of the primary members per meter square of the building. Furthermore, unlike conventional hot-rolled steel portal frames, where the purlin spacing is typically around $1.8 \mathrm{~m}$, with cold-formed steel portal frames there is often a need to have a smaller spacing in order to provide more restraint to the column and rafter members. 
Although purlins are secondary members, they can account for approximately $30 \%$ of the total cost of the building. For smaller buildings, having frame spacings (and therefore purlin spans) of around $4 \mathrm{~m}$, and purlin spacings of $1 \mathrm{~m}$, the specification of even the smallest zed-section available can result in an over-design by as much as $30 \%$.

In the UK, the conventional purlin used are zed-sections. An alternative to the use of zed-sections for purlins is the top-hat section (see Fig. 2). Such sections can be expected to perform better than zed purlins against lateral torsional buckling. Furthermore, they are simple to install on site and, unlike zed purlins, do not require the installation of anti-sag rods or cleats. The authors have recently described and presented experimental and numerical investigation on cold-formed steel top-hat section under bending [6].

The behaviour of hat shaped sections has received limited attention in the literature. Fig. 3 (a) shows the hat shaped sections tested by Acharya and Schuster [7]. Pastor and Roure [8, 9] tested un-lipped channel sections (see Fig. 3 (b)), considering the formation of a plastic hinge. A finite element analysis methodology was implemented to simulate the post collapse behaviour. Honfi [10] considered the design optimization of hat shaped sections (see Fig. 3 (c)) by use of a genetic algorithm.

In this paper, twenty-seven full-scale experimental tests on top-hat purlin sections are described. Details of the top-hat sections that will be considered in this paper are shown in Fig. 4. The moment capacities obtained experimentally are compared against those predicted by Eurocode 3 and non-linear elasto-plastic finite element analyses. A parametric study is then undertaken. Design recommendations are provided in the form of bar charts that can be used to assist designers. 


\section{Experimental investigation}

\subsection{Test specimens}

Twenty-seven full-scale tests were conducted on the four different geometries of top-hat sections under four point bending, eleven tests in the under uplift and sixteen tests under gravity load. Full details of these full-scale tests can be found in Potter [11] and Uzzaman et al. [6]. Two loading directions were considered: uplift (representing wind uplift load) and gravity load (representing vertical snow load). The nominal and measured cross-section of the four types of top-hat sections are shown in Fig. 4a, b, c and d. The nominal thickness of the top-hat sections was 1 $\mathrm{mm}$.

\subsection{Specimens labelling}

As can be seen in Table 1, the specimens were labelled such that the loading direction, the nominal overall height dimension of the specimen and number of test. For example, the labels "U-61-N1" and "G-61-N1" are explained as follows:

- The first notation defines loading direction of the test. " $U$ " represents loading under uplift direction and " $G$ " represents loading under gravity direction.

- Second notation defines the nominal overall height dimension of the tophat section in millimetres $(61=61 \mathrm{~mm}, 100=100 \mathrm{~mm}, 120=120 \mathrm{~mm}$, $150=150 \mathrm{~mm})$.

- $\quad$ "N1" represents the number of repeat tests on same top-hat section. 


\subsection{Material properties}

Tensile coupon tests were carried out to determine the material properties of the top-hat specimens. The tensile coupons were taken from the centre of the web plate in the longitudinal direction of the untested specimens. The tensile coupons were prepared and tested according to the British Standard for Testing and Materials [12] for the tensile testing of metals using $12.5 \mathrm{~mm}$ wide coupons of a gauge length of $50 \mathrm{~mm}$. The coupons were tested in an MTS displacement controlled testing machine using friction grips. A calibrated extensometer of $50 \mathrm{~mm}$ gauge length was used to measure the longitudinal strain. Table 2 summarises the average yield and ultimate strengths of the top-hat sections, measured from three tensile coupons taken from top-hat sections, which includes the measured static $2 \%$ proof stress $\left(\sigma_{0.2}\right)$ and the tensile ultimate strength $\left(\sigma_{u}\right)$. The typical stress-strain curve for the section U61 is shown in Fig. 5.

\subsection{Test rig and procedure}

Four types of top-hat sections were tested under four point bending. Fig. 6(a) shows a schematic drawing of the test set up. At the ends of the sections, the top hats were bolted to pivoting support blocks. Load was applied through the timber blocks to prevent local crushing at the loading points. For the uplift loading direction the top-hat sections were turned bottom upwards (see Fig. 6(c)); similarly, for the gravity loading direction the top-hat sections were turned bottom downwards (see Fig. 6(b)); the loading jack was moved downwards in both tests. 
Details of the test-rig supports are shown in Fig. 7. As can be seen, elongated holes are used to represent a pinned connection. The test rig supports were designed such that rotation and horizontal translation could occur freely at the supports. In order to prevent axial force in the top-hat sections, elongated holes were provided through the introduction of a pin located in a kidney shaped hole. The bolts at the supports were also only finger-tightened. Before each test, load cycles to remove the slack from the top-hat sections were conducted.

\subsection{Test Results}

The dimensions of the test specimens and the experimental ultimate loads $\left(\mathrm{P}_{\mathrm{EXP}}\right)$ are shown in Table 1a and Table $1 \mathrm{~b}$ for the case of uplift and gravity loading direction, respectively. For each specimen, the ultimate moment capacities $\left(\mathrm{M}_{\mathrm{u}}^{\mathrm{EXP}}\right)$ are also calculated and are also shown in Table 1.

\section{Eurocode 3 bending resistance}

As shown in Fig. 8, the same notation as described in Section 5.1 of BS EN 1993-1-3 has been used [13]. According to Section 5.2 of BS EN 1993-1-3, the cross-sections considered in this paper are outside the range of validity of width-tothickness ratio, thus design by calculation is only permitted if validated against test results. Four top-hat sections presented in Fig. 4 were analysed. Calculations to the BS EN 1993-1-3 [13] were undertaken for one purlin of each size in both uplift and downward loading direction. The structural analysis software Scia Engineer 2012 [14] was used to calculate effective cross section properties in bending. In accordance with BS EN 10326 [15], the steel grade used for top-hats was S550GD+AZ150. 
It should be noted that the measured (or actual) geometry of the top hat purlins tested was different from the nominal geometry provided by the manufacturer. Table 3 shows the manufacturing tolerances, from which it can be seen that the sections could be considered as being slightly asymmetrical. For this reason, the geometry used in the design calculations was measured using a photographic imaging process in order to take into account, amongst others, the asymmetry and manufacturing imperfections. The longitudinal stresses, based on the principal axis, were used when calculating the effective width and effective thicknesses of the cross sections. For the purposes of the design calculations, the rounded corners were sub-divided into four segments; the intermediate stiffeners in both web and flanges were also modelled. The moment capacities $\left(\mathrm{M}_{\mathrm{u}}^{\mathrm{EC} 3}\right)$ predicted by EC3 are shown in Table 4 .

\section{$4 \quad$ Numerical Investigation}

\subsection{General}

The non-linear elasto-plastic general purpose finite element program ANSYS (2013) was used to simulate the top-hat sections subjected to pure bending. Uzzaman et al (16-19) developed finite element models for web crippling behaviour of cold-formed steel beams with openings and similar techniques were adopted to developed finite element models. In the finite element model, the measured crosssection dimensions (see Fig.4) (i.e. imperfect geometry) and the material properties obtained from the tests were used. The model was based on the centreline dimensions of the measured cross-sections. Specific modeling issues are described in the following sections.

\subsection{Geometry and material properties}


Owing to symmetry about the vertical plane, only one-half of the test set-up was modelled (see Fig. 9). The value of Young's modulus and Poisson's ratio was taken as $210 \times 10^{3} \mathrm{~N} / \mathrm{mm}^{2}$ and 0.3 , respectively. The material non-linearity was incorporated in the finite element model by specifying 'true' values of stresses and strains. To represent the nonlinear material behaviour, stress-strain curves were directly obtained from the tensile tests and converted into true stress vs true strain curves using the following equations specified in the ANSYS manual (2013) [20]:

$$
\begin{aligned}
& \sigma_{\text {true }}=\sigma_{\text {eng }}\left(\varepsilon_{\text {eng }}+1\right) \\
& \varepsilon_{\text {true }}=\ln \left(\varepsilon_{\text {eng }}+1\right)
\end{aligned}
$$

The full section true stress vs strain curves obtained from the above relationships were represented using data points and entered into ANSYS. The material model was a multi-linear isotropic hardening material model (MISO). The typical true stress-strain curves for section U-61 is shown in Fig. 5.

\subsection{Element type and mesh sensitivity}

Fig. 9 shows details of a typical finite element mesh of the top-hat section. The effect of different element sizes in the cross-section of the top-hat section was investigated to provide both accurate results and reduced computation time. The finite element mesh sizes was $10 \mathrm{~mm} \times 10 \mathrm{~mm}$. Three elements were used around the inside corner radius that forms the bend. Along the length of the top-hat sections, the number of elements was chosen so that the aspect ratio of the elements was as close to one as possible. Mesh sensitivity analyses were performed to verify the number of elements. The top-hat sections were modeled using the 4-noded shell element SHELL181. 


\subsection{Loading and boundary conditions}

The nodes of the cold-formed top-hat steel section were restrained to represent the vertical symmetry condition. Displacement control was used, with an imposed displacement applied to the nodes along the width of the top-hat section. Supports were modelled through in line regions. The nodes in line regions were restrained in the $\mathrm{Y}$ direction. Nodes were restrained in the $\mathrm{Z}$ direction where the bottom flanges of the top-hat section were connected to the support plates.

\subsection{Verification of stiffness of finite element model}

In order to validate the finite element model, the experimental moment capacity was compared against the ultimate moment predicted by the finite element analysis. A comparison of the test results $\left(\mathrm{M}_{\mathrm{u}}{ }^{\mathrm{EXP}}\right)$ with the numerical results $\left(\mathrm{M}_{\mathrm{u}}{ }^{\mathrm{FEA}}\right)$ of the top-hat ultimate moment is shown in Table 5 for the uplift and gravity loading direction.

A graph of applied bending moment versus central deflection, comparing the experimental results and the finite element results, are shown in Fig. 10. It can be seen that good agreement in stiffness has been achieved for the finite element results with the experimental results for both TH61 and TH100. In terms of failure modes, the same ultimate load failure mode from the experimental tests was observed in the finite element models for both loading directions, as shown in Fig. 11 and Fig. 12. As mentioned previously, as the two deeper sections were found to be susceptible to distortional buckling in the wind uplift direction, TH61 and TH100 sections are more suitable for comparison against the zed-sections in the study described in Sections 5 and 6. 


\section{$5 \quad$ Parametric Study}

A parametric study comprising 32 models was conducted on TH61 and TH100 sections. Four different thicknesses of $1.0 \mathrm{~mm}, 1.2 \mathrm{~mm}, 1.4 \mathrm{~mm}$ and $1.6 \mathrm{~mm}$ are considered. Two different steel grades of $390 \mathrm{MPa}$ and $450 \mathrm{MPa}$ were also considered. For the specimen labelling, "M390" and T1.0 represents the grade of the material (e.g. M390 = $390 \mathrm{MPa}$ ) and thickness of the top-hat section (e.g. T1 $0=1$ $\mathrm{mm}$ ). It should be noted that $\mathrm{TH} 120$ and $\mathrm{TH} 150$ sections were excluded from the parametric study as they were found to be too susceptible to distortional buckling under uplift to be efficient when compared with the zed-sections.

For comparison, the efficiency of the top-hat sections will be compared against those of a typical zed-section. Fig. 13 shows the nominal dimensions of the smallest zed-section purlin available by Steadmans [21, 22]. The zed-section is available in thicknesses of $1.4 \mathrm{~mm}, 1.5 \mathrm{~mm}$ and $1.6 \mathrm{~mm}$. The grade of the material is $390 \mathrm{MPa}$.

Table 6 summarises the section properties and results of the parametric study. The ratio of the ultimate bending capacity divided by the cross- sectional moment of inertia $\left(\mathrm{M}_{\mathrm{u}}^{\text {FEA } / \mathrm{I})}\right.$ is also shown. Table 7 shows the same values for $\mathrm{Z} 140$ purlin sections. The values shown have been determined from load-span tables provided by Steadmans $[21,22]$. The moment capacity of the zed-section was calculated based on the permissible uniformly distributed load of a single-span butted purlin. It is not stated if the manufacturers' load-span tables are based on experimental test results, and if the beneficial effect of cladding has been included.

Fig. 14 shows the variation of moment capacity against slenderness (D/t), for the top-hat and zed-sections. As can be seen, the moment capacity increases as the slenderness decreases. It can be seen that use of $450 \mathrm{MPa}$ grade steel is 
advantageous for the top-hat sections with smaller values of slenderness. As distortional buckling governs the uplift moment capacity of the top hat, this mode of failure is less sensitive to the steel grade. Generally, increasing the grade of steel from $390 \mathrm{MPa}$ to $450 \mathrm{MPa}$ resulted in an average capacity increase of $17 \%$ under the gravity load case and only $8 \%$ under the uplift load case.

\section{Application to purlin design}

The design of purlins is considered for the geometry of portal frame shown in Fig. 15. As can be seen, a frame of span of $12 \mathrm{~m}$, height of eaves of $3 \mathrm{~m}$ and roof pitch of $10^{\circ}$ is adopted. Using this geometry of frame, frame spacings of $3 \mathrm{~m}, 4 \mathrm{~m}, 5$ $\mathrm{m}$, and $6 \mathrm{~m}$ are investigated. The length of the building is assumed as being three times that of the frame spacing.

The loads applied to the frame (and therefore to the purlins) were as follows.

Dead Load (DL): Cladding and service loads on the slope and self-weight of columns, rafters, purlins, and side rails of $0.15 \mathrm{kN} / \mathrm{m}^{2}$.

Live Load (LL): $\quad$ Snow load of $0.6 \mathrm{kN} / \mathrm{m}^{2}$

The following site conditions were assumed, all considered as being typical in the UK.

Basic wind speed: $24 \mathrm{~m} / \mathrm{s}$

Site altitude: $50 \mathrm{~m}$

Distance to the sea: $10 \mathrm{~km}$

Directional factor: 1

Seasonal factor: 1 
In accordance with BS 6399 [23], the design wind pressures (p) were calculated as follows Equation 3.

$$
p=q_{s}\left(C_{p e}-C_{p i}\right)
$$

Where, Cpe is the external pressure coefficient

Cpi is the internal pressure coefficient.

For buildings of normal permeability, without dominant openings, $\mathrm{C}_{\mathrm{pi}}$ has a minimum value of -0.3 for negative pressure, and a maximum value of +0.2 for positive pressure. Two critical wind load cases were chosen for wind pressure (WP) and wind uplift (WU). The wind pressures for localised pressure zones were averaged into a conservative uniformly distributed load as described in SCI design guide for BS6399 [23].

The purlins were checked for the following four ultimate limit state load combinations (ULCs) [24].

$$
\begin{aligned}
& \mathrm{ULC} 1=1.4 \mathrm{DL}+1.6 \mathrm{LL} \\
& \mathrm{ULC} 2=1.2 \mathrm{DL}+1.2 \mathrm{LL}+1.2 \mathrm{WP} \\
& \mathrm{ULC} 3=1.0 \mathrm{DL}+1.4 \mathrm{WU}
\end{aligned}
$$

The purlins were also checked at the serviceability limit state for the following three serviceability load combinations (SLCs).

$$
\begin{aligned}
& \text { SLC1 }=1.0 \mathrm{LL} \\
& \text { SLC2 }=1.0 \mathrm{WP} \\
& \text { SLC3 }=1.0 \mathrm{WU}
\end{aligned}
$$

The serviceability deflection limits adopted were the maximum of span /150 and $30 \mathrm{~mm}$ [25]. Fig. 16(a) shows the variation of maximum permissible purlin spacing against frame spacing for the Top-hat 61. The horizontal line at $2 \mathrm{~m}$ 
indicates the maximum spanning capability of the cladding [21]. Therefore, even if the maximum purlin spacing can be greater than $2 \mathrm{~m}$, the purlin spacing needs to be reduced to $2 \mathrm{~m}$ in order to accommodate the design of the cladding. It can be seen from Fig. 16(a) that the effect of the higher steel grade of $450 \mathrm{MPa}$ is only beneficial for purlin spans less than $4 \mathrm{~m}$; this indicates that for spans greater than $4 \mathrm{~m}$, the design is controlled by serviceability.

Fig. 16(b) shows the variation of maximum permissible purlin spacing against frame spacing for the Top-hat 100 . The same results for the Z-140 are also shown. As mentioned previously, Z-140 is the smallest zed section available in the manufactures' catalogue [22]. It can be seen that if zed sections are used for purlin spans less than $4 \mathrm{~m}$ that the purlins will be over designed.

Fig. 17(a) shows, for the case of a purlin span of $3 \mathrm{~m}$, the purlin weight per square meter (on plan). The maximum permissible spacing is shown above each of the bars. As can be seen, the weight of TH61-T1.6 and TH100-T1.0 are competitive compared with the zed-sections. However, this does not take into account the fact that the cost of the $1.0 \mathrm{~mm}$ steel by volume is likely to be cheaper than that of the zed-sections. It also does not take into account the fact that the top-hat sections are easier to install on site.

Fig. 17(b) shows the same results for the case of a purlin span of $4 \mathrm{~m}$. As can be seen, the TH100-T1.4 is the most competitive top-hat purlin, with a weight approximately only $20 \%$ higher than that of the zed-sections. Fig. 17(c) and (d) show the same results for the case of purlin spans of $5 \mathrm{~m}$ and $6 \mathrm{~m}$, respectively. As expected, for these spans, the zed-sections are more competitive.

\section{Conclusions}


This paper has considered the viability of using top-hat sections for purlins in cold-formed steel portal frames. For such frames, the optimal building may have a frame spacing less than the $6 \mathrm{~m}$ used typically in hot-rolled steel construction. Furthermore, in cold-formed steel portal frames, the purlin spacing may need to be smaller in order to provide more lateral stability to the primary column and rafter members.

An experimental investigation of cold formed top-hat sections subjected to four point bending has been presented. The results are compared against BS EN 1993-1-3 design calculations and finite element analysis.

The finite element model was used to undertake a parametric study comprising different thicknesses and strengths of the top-hat sections. The results were then used to construct bar charts showing the efficiency of the top-hat sections compared with the zed-section in terms of weight of steel required per square meter on the roof. While the zed-sections were shown to be more efficient for all cases, the comparison showed that top-hat sections performed similarly for frame spacings of $3 \mathrm{~m}$ and $4 \mathrm{~m}$. For frame spacings of $5 \mathrm{~m}$ and $6 \mathrm{~m}$, use of top-hat sections would not be efficient.

However, this comparison in terms of weight ignores some of the advantages of the top-hat sections in terms of ease of installation on site, as well as beneficial effects such as stressed-skin action. Furthermore, a comparison in terms of cost would be more favourable for the top-hat section of thinner gauge.

The complete study demonstrates how modern numerical analysis techniques of the sort that are now readily available to the research community may be used to develop design guidance for complex structural components. Such an approach 
greatly reduces the need for expensive and time consuming laboratory study, whilst maintaining realistic and safe coverage of all important structural issues.

\section{Acknowledgements}

The Authors would like to acknowledge Capital Steel Buildings Ltd. for providing the test specimens. The experimental work was carried out by Angus Potter, as part of his undergraduate research project. The authors also wish to thank Mr Chris Cameron and Mr Andrew Crockett for their assistance in preparing the specimens and carrying out the experimental testing. 


\section{References}

[1] J.B.P. Lim and D.A. Nethercot, "FE assisted design of the eaves bracket of a cold-formed steel portal frame", Steel \& Composite Structures, Vol. 2, No. 6, Pages 411-428, 2002.

[2] Target Zero, Guidance on the design and construction of sustainable, low carbon warehouse buildings, 2011, Tata Steel and the British Constructional Steelwork Association. p. 6.

[3] A.M. Wrzesien, J. B. P Lim, Y. Xu, I. MacLeod, and R. M. Lawson, Effect of stressed skin action on the behaviour of cold-formed steel portal frames. Engineering Structures, 2015. 105: p. 123-136.

[4] D.T. Phan, J.B.P. Lim, W. Sha, C.S.Y. Siew, T.T. Tanyimboh, H. Issa, F.A. Mohammad, Design optimization of cold-formed steel portal frames taking into account the effect of building topology. Engineering Optimization, 2013. 45(4): p. 415-433.

[5] D.T. Phan, J.B.P. Lim, T.T. Tanyimboh, A.M. Wrzesien, W. Sha and R. M. Lawson, Optimal design of cold-formed steel portal frames for stressed-skin action using genetic algorithm. Engineering Structures, 2015. 93(0): p. 36-49.

[6] A. Uzzaman, A.M. Wrzesien, R. Hamilton, J.B.P Lim , D. Nash, "Investigation of Cold-Formed Steel Top-Hat Sections Under Bending”, in B.H.V. Topping, P. Iványi, (Editors), Proceedings of the Fourteenth International Conference on Civil, Structural and Environmental Engineering Computing, Civil-Comp Press, Stirlingshire, UK, Paper 15, 2013. doi:10.4203/ccp.102.15. 
[7] V.V. Acharya, R. M. Schuste, "Bending tests of hat sections with multiple longitudinal stiffeners", Fourteenth international specialty conference on coldformed steel structures, St. Louis, Missouri, 1998.

[8] M.M. Pastor, F. Roure, "Open cross-section beams under pure bending I. Experimental investigations”, Thin-Walled Structures, Volume 46, Pages 476483, 2008.

[9] M.M. Pastor, F. Roure, "Open cross-section beams under pure bending II. Finite element simulation", Thin-Walled Structures, Volume 47, Pages 514$521,2009$.

[10] D. Honfi, "Neural network based genetic algorithm optimization of hat-shaped beams", Proceedings of the Fifth International Conference on Engineering Computational Technology, Civil-Comp Press, Paper 52, Stirlingshire, 2006.

[11] A. Potter, "A comparison between physical testing results and numerical calculation methods pertaining to the determination of moment capacity and deflection", Final year project thesis, University of Strathclyde, Glasgow, 2010.

[12] BS EN 2001. 10002-1, "Tensile testing of metallic materials method of test at ambient temperature", British Standards Institution, 2001.

[13] BS EN 1993-1-3, Eurocode 3, "Design of Steel Structures; Part 1.3: Supplementary Rules for Cold Formed Thin Gauge Members and Sheeting”, Brussels, Belgium, 1996.

[14] Scia Engineer software "Release 2012- User's Manuals", Nemetschek Scia, 2012.

[15] BS EN 10346:2004, “Continuously hot-dip coated steel flat products. Technical delivery conditions”, July, 2004. 
[16] A. Uzzaman, J.B.P. Lim, D. Nash, J. Rhodes, B. Young, Web crippling behaviour of cold-formed steel channel sections with offset web holes subjected to interior-two-flange loading, Thin-Walled Structures, 50 (2012) $76-86$.

[17] A. Uzzaman, J.B.P. Lim, D. Nash, J. Rhodes, B. Young, Effect of offset web holes on web crippling strength of cold-formed steel channel sections under end-two-flange loading condition, Thin-Walled Structures, 65 (2013) 34-48.

[18] A. Uzzaman, J.B.P. Lim, D. Nash, J. Rhodes, B. Young, Cold-formed steel sections with web openings subjected to web crippling under two-flange loading conditions-part I: Tests and finite element analysis, Thin-Walled Structures, 56 (2012) 38-48.

[19] A. Uzzaman, J.B.P. Lim, D. Nash, J. Rhodes, B. Young, Cold-formed steel sections with web openings subjected to web crippling under two-flange loading conditions-part II: Parametric study and proposed design equations, Thin-Walled Structures, 56 (2012) 79-87.

[20] ANSYS “Release 11- User’s Manuals”, ANSYS Inc, 2011.

[21] Steadmans 'Purlins, rails and eaves beams design guide' A Steadman \& Son, January 2012.

[22] Steadmans "Purlins, rails and eaves beams load tables' A Steadman \& Son, June 2011 .

[23] BS 6399-2 (1997). Loading for buildings. Code of practice for wind loads. London, British Standards Institution.

[24] SCI 'Guide to evaluating design wind load to BS 6399-2.1997' The Steel Construction Institute, 2003. 
[25] Wrzesien, A. M., J. B. P. Lim, et al. (2009). Stressed skin action of the roof systems with hat-shaped purlins. 9th SSTA Conference, Gdansk-Jurata, Poland, CRC Press.

Table 1: Specimen dimensions and experimental failure load

(a) Under uplift loading

\begin{tabular}{ccccccc}
\hline Specimen & $\begin{array}{c}\text { Overall } \\
\text { width }\end{array}$ & $\begin{array}{c}\text { Overall } \\
\text { height }\end{array}$ & $\begin{array}{c}\text { Thickness } \\
\text { excluding } \\
\text { galvanizing } \\
\text { coating }\end{array}$ & $\begin{array}{c}\text { Test } \\
\text { Span }\end{array}$ & $\begin{array}{c}\text { Load at } \\
\text { Failure }\end{array}$ & $\begin{array}{c}\text { Moment capacity } \\
\text { obtained from test }\end{array}$ \\
\hline & $(\mathrm{mm})$ & $(\mathrm{mm})$ & $(\mathrm{mm})$ & $(\mathrm{m})$ & $(\mathrm{kN})$ & $\mathrm{M}_{\mathrm{u}}^{\text {EXP }}$ \\
\hline U-61-N1 & 143.45 & 57.44 & 0.99 & 2.50 & 3.39 & $(\mathrm{kN}-\mathrm{m})$ \\
U-61-N2 & 142.79 & 57.23 & 0.99 & 2.50 & 3.42 & 1.44 \\
$\mathrm{U}-61-\mathrm{N} 3$ & 141.75 & 57.23 & 0.99 & 2.50 & 3.40 & 1.45 \\
$\mathrm{U}-100-\mathrm{N} 1$ & 163.50 & 99.00 & 0.96 & 2.75 & 3.71 & 1.81 \\
$\mathrm{U}-100-\mathrm{N} 2$ & 162.00 & 98.50 & 0.96 & 2.75 & 3.77 & 1.84 \\
$\mathrm{U}-100-\mathrm{N} 3$ & 167.50 & 98.50 & 0.96 & 2.75 & 3.75 & 2.83 \\
$\mathrm{U}-120-\mathrm{N} 1$ & 181.50 & 116.00 & 0.99 & 3.75 & 2.89 & 2.07 \\
$\mathrm{U}-120-\mathrm{N} 2$ & 183.00 & 116.00 & 0.97 & 3.75 & 2.80 & 2.71 \\
$\mathrm{U}-150-\mathrm{N} 1$ & 190.00 & 150.25 & 0.99 & 4.00 & 3.39 & 2.64 \\
$\mathrm{U}-150-\mathrm{N} 2$ & 192.00 & 149.50 & 0.98 & 4.00 & 3.30 & 2.75 \\
$\mathrm{U}-150-\mathrm{N} 3$ & 191.50 & 150.00 & 0.99 & 4.00 & 3.44 & \\
\hline
\end{tabular}

b) Under gravity loading 


\begin{tabular}{ccccccc}
\hline Specimen & $\begin{array}{c}\text { Overall } \\
\text { width }\end{array}$ & $\begin{array}{c}\text { Overall } \\
\text { height }\end{array}$ & $\begin{array}{c}\text { Thickness } \\
\text { excluding } \\
\text { galvanizing } \\
\text { coating } \\
(\mathrm{mm})\end{array}$ & $\begin{array}{c}\text { Test } \\
\text { Span }\end{array}$ & $\begin{array}{c}\text { Load at } \\
\text { Failure } \\
\mathrm{P}_{\text {EXP }}\end{array}$ & $\begin{array}{c}\text { Moment capacity } \\
\text { obtained from test } \\
\mathrm{M}_{\mathrm{u}}^{\text {EXP }}\end{array}$ \\
\hline G-61-N1 & 143.74 & 57.43 & 0.99 & 2.50 & 4.12 & $(\mathrm{kN})$ \\
G-61-N2 & 144.42 & 56.96 & 0.98 & 2.50 & 4.09 & 1.75 \\
G-61-N3 & 143.25 & 57.55 & 0.98 & 2.50 & 4.18 & 1.74 \\
G-61-N4 & 144.28 & 57.13 & 0.98 & 2.50 & 4.19 & 1.78 \\
G-100-N1 & 166.00 & 99.00 & 0.96 & 2.75 & 6.89 & 3.36 \\
G-100-N2 & 168.00 & 98.55 & 0.97 & 2.75 & 6.86 & 3.34 \\
G-100-N3 & 167.50 & 99.25 & 0.97 & 2.75 & 6.55 & 3.19 \\
G-100-N4 & 163.50 & 98.75 & 0.99 & 2.50 & 7.79 & 3.31 \\
G-120-N1 & 184.00 & 115.00 & 0.99 & 3.75 & 5.67 & 4.18 \\
G-120-N2 & 189.00 & 114.75 & 0.98 & 3.75 & 5.68 & 4.19 \\
G-120-N3 & 182.00 & 115.75 & 0.98 & 3.75 & 5.66 & 4.17 \\
G-120-N4 & 181.50 & 115.25 & 0.98 & 3.75 & 5.61 & 4.53 \\
G-150-N1 & 192.00 & 149.25 & 0.98 & 4.00 & 5.66 & 4.63 \\
G-150-N2 & 190.00 & 149.50 & 0.98 & 4.00 & 5.79 & 4.65 \\
G-150-N3 & 193.50 & 149.00 & 0.99 & 4.00 & 5.81 & 4.65 \\
G-150-N4 & 194.00 & 149.25 & 0.98 & 3.50 & 6.89 & \\
\hline
\end{tabular}

Table 2: Mechanical properties measured from tensile coupon tests

\begin{tabular}{ccc} 
Specimen & $\begin{array}{c}\sigma_{0.2} \\
(\mathrm{MPa})\end{array}$ & $\begin{array}{c}\sigma_{\mathrm{u}} \\
(\mathrm{MPa})\end{array}$ \\
\hline $\mathrm{U}-61$ & 573 & 593 \\
$\mathrm{G}-61$ & 579 & 598 \\
$\mathrm{U}-100$ & 538 & 560 \\
$\mathrm{G}-100$ & 537 & 556 \\
$\mathrm{U}-120$ & 551 & 570 \\
$\mathrm{G}-120$ & 546 & 574 \\
$\mathrm{U}-150$ & 511 & 528 \\
$\mathrm{G}-150$ & 516 & 534 \\
\hline
\end{tabular}

Table 3: Manufacturing tolerances according to BS EN 1090-2 [3]

\begin{tabular}{clcccc}
\hline Specimen & $\begin{array}{l}\text { Element } \\
\text { type }\end{array}$ & $\begin{array}{c}\text { Nominal } \\
\text { dimension } \\
(\mathrm{mm})\end{array}$ & $\begin{array}{c}\text { Actual } \\
\text { dimension } \\
(\mathrm{mm})\end{array}$ & $\begin{array}{c}\text { Permitted } \\
\text { Deviation } \\
(\mathrm{mm})\end{array}$ & $\begin{array}{c}\text { Actual } \\
\text { deviation } \\
(\mathrm{mm})\end{array}$ \\
\hline \multirow{3}{*}{ Top-Hat-61 } & Flange top (a) & 43.50 & 50.60 & -0.87 & 7.10 \\
& Left height (h) & 60.80 & 57.20 & -1.22 & -3.60 \\
& Right height (h) & 60.80 & 57.20 & -1.22 & -3.60 \\
& Left flange bottom (c) & 27.80 & 27.10 & -0.56 & -0.70 \\
& Right flange bottom (c) & 27.80 & 26.00 & -0.56 & -1.80
\end{tabular}




\begin{tabular}{llcccc} 
& Left Lip (d) & 4.60 & 4.70 & -0.06 & 0.10 \\
& Right Lip (d) & 4.60 & 4.20 & -0.06 & -0.40 \\
\cline { 2 - 5 } Top-Hat-100 & Flange top (a) & 43.50 & 43.10 & -0.87 & -0.40 \\
& Left height (h) & 99.80 & 98.60 & -2.00 & -1.20 \\
& Right height (h) & 99.80 & 97.30 & -2.00 & -2.50 \\
& Left flange bottom (c) & 27.80 & 25.70 & -0.56 & -2.10 \\
& Right flange bottom (c) & 27.80 & 25.50 & -0.56 & -2.30 \\
& Left Lip (d) & 5.00 & 5.60 & -0.06 & 0.60 \\
& Right Lip (d) & 5.00 & 6.90 & -0.06 & 1.90 \\
\cline { 2 - 5 } Top-Hat-120 & Flange top (a) & 43.50 & 43.20 & -0.87 & -0.30 \\
& Left height (h) & 119.80 & 117.90 & -2.40 & -1.90 \\
& Right height (h) & 119.80 & 117.00 & -2.40 & -2.80 \\
& Left flange bottom (c) & 27.80 & 25.10 & -0.56 & -2.70 \\
& Right flange bottom (c) & 27.80 & 25.10 & -0.56 & -2.70 \\
& Left Lip (d) & 5.00 & 10.60 & -0.06 & 5.60 \\
& Right Lip (d) & 5.00 & 10.80 & -0.06 & 5.80 \\
\cline { 2 - 5 } Top-Hat-150 & Flange top (a) & 43.50 & 42.90 & -0.87 & -0.60 \\
& Left height (h) & 149.80 & 148.80 & -1.22 & -1.00 \\
& Right height (h) & 149.80 & 147.00 & -1.22 & -2.80 \\
& Left flange bottom (c) & 21.50 & 27.00 & -0.56 & 5.50 \\
& Right flange bottom (c) & 21.50 & 26.70 & -0.56 & 5.20 \\
& Left Lip (d) & 5.00 & 10.70 & -0.06 & 5.70 \\
& Right Lip (d) & 5.00 & 8.60 & -0.06 & 3.60 \\
\hline
\end{tabular}

Table 4: Moment capacity accordance with BS EN 1993-1-3 [13]

(a) Under uplift loading

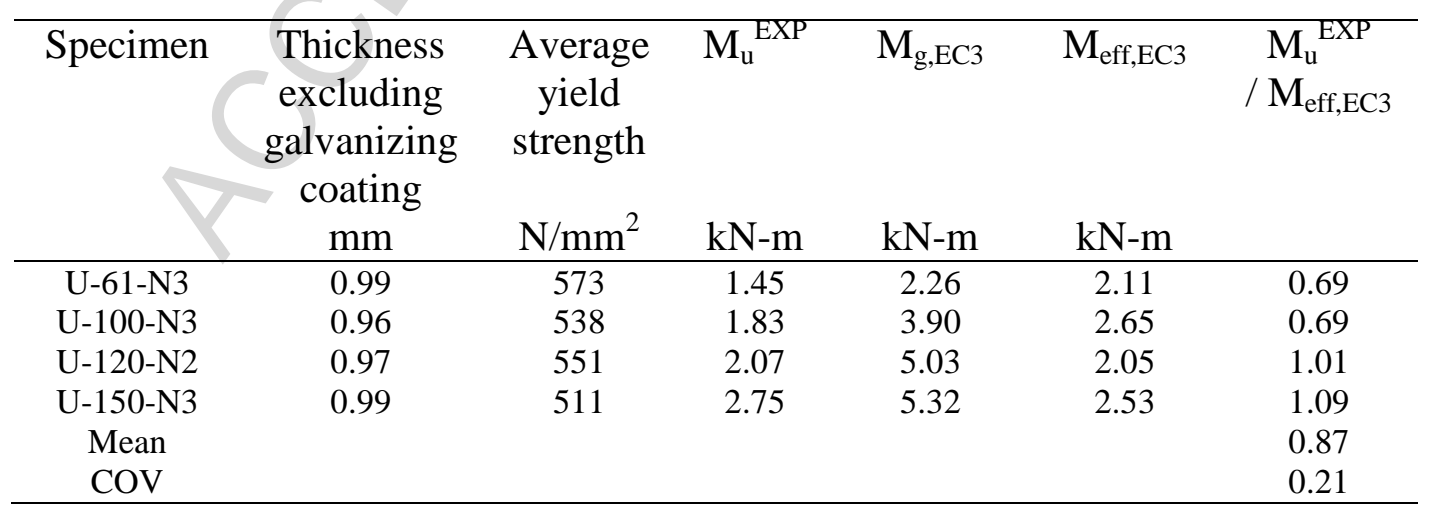

b) Under gravity loading 


\begin{tabular}{|c|c|c|c|c|c|c|}
\hline Specimen & $\begin{array}{l}\text { Thickness } \\
\text { excluding } \\
\text { galvanizing } \\
\text { coating } \\
\text { mm }\end{array}$ & $\begin{array}{l}\text { Average } \\
\text { yield } \\
\text { strength } \\
\left(\mathrm{N} / \mathrm{mm}^{2}\right)\end{array}$ & $\mathrm{M}_{\mathrm{u}}^{\mathrm{EXP}}$ & $\mathrm{M}_{\mathrm{g}, \mathrm{EC} 3}$ & $\mathrm{M}_{\mathrm{eff}, \mathrm{EC} 3}$ & $\begin{array}{c}\mathrm{M}_{\mathrm{u}}^{\mathrm{EXP}} \\
/ \mathrm{M}_{\mathrm{eff}, \mathrm{EC} 3}\end{array}$ \\
\hline G-61-N1 & 0.99 & 579 & 1.75 & 2.26 & 2.26 & 0.77 \\
\hline G-100-N2 & 0.97 & 537 & 3.34 & 3.90 & 3.62 & 0.92 \\
\hline G-120-N2 & 0.99 & 546 & 4.19 & 5.03 & 4.61 & 0.91 \\
\hline G-150-N2 & 0.98 & 516 & 4.63 & 5.32 & 5.08 & 0.91 \\
\hline Mean & & & & & & 0.88 \\
\hline COV & & & & & & 0.08 \\
\hline
\end{tabular}

Table 5: Comparison of experimental test results and finite element analysis results (a) Under uplift loading

\begin{tabular}{cccccc}
\hline Specimen & Thickness & $\begin{array}{c}\text { Average yield } \\
\text { strength } \\
\mathrm{N} / \mathrm{mm}^{2}\end{array}$ & $\mathrm{M}_{\mathrm{u}}{ }^{\text {EXP }}$ & $\mathrm{M}_{\mathrm{u}}^{\text {FEA }}$ & $\begin{array}{c}\mathrm{M}_{\mathrm{u}}^{\text {EXP }} \\
/ \mathrm{M}_{\mathrm{u}}^{\text {FEA }}\end{array}$ \\
\hline U-61-N1 & $(\mathrm{mm})$ & 573 & 1.44 & 1.44 & 1.00 \\
U-61-N2 & 0.96 & 573 & 1.45 & 1.43 & 1.02 \\
U-61-N3 & 0.96 & 573 & 1.45 & 1.43 & 1.01 \\
U-100-N1 & 0.99 & 538 & 1.81 & 2.15 & 0.84 \\
U-100-N2 & 0.97 & 538 & 1.84 & 2.17 & 0.85 \\
U-100-N3 & 0.99 & 538 & 1.83 & 2.15 & 0.85 \\
U-120-N1 & 0.98 & 551 & 2.13 & 2.68 & 0.80 \\
U-120-N2 & 0.99 & 551 & 2.07 & 2.60 & 0.80 \\
U-150-N1 & 0.96 & 511 & 2.71 & 3.13 & 0.87 \\
U-150-N2 & 0.96 & 511 & 2.64 & 2.97 & 0.89 \\
U-150-N3 & 0.96 & 511 & 2.75 & 3.06 & 0.90 \\
Mean & & & & & 0.89 \\
COV & & & & & \\
\hline
\end{tabular}


b) Under gravity loading

\begin{tabular}{|c|c|c|c|c|c|}
\hline Specimen & Thickness & $\begin{array}{l}\text { Average yield } \\
\text { strength } \\
\mathrm{N} / \mathrm{mm}^{2}\end{array}$ & $\begin{array}{l}\mathrm{M}_{\mathrm{u}}^{\mathrm{EXP}} \\
(\mathrm{kN}-\mathrm{m})\end{array}$ & $\begin{array}{c}\mathrm{M}_{\mathrm{u}}^{\mathrm{FEA}} \\
(\mathrm{kN}-\mathrm{m})\end{array}$ & $\begin{array}{l}\mathrm{M}_{\mathrm{u}}^{\text {EXP }} \\
/ \mathrm{M}_{\mathrm{u}}{ }^{\text {FEA }}\end{array}$ \\
\hline G-61-N1 & 0.99 & 579 & 1.75 & 1.96 & 0.89 \\
\hline G-61-N2 & 0.98 & 579 & 1.74 & 1.90 & 0.91 \\
\hline G-61-N3 & 0.98 & 579 & 1.78 & 1.93 & 0.92 \\
\hline G-61-N4 & 0.98 & 579 & 1.78 & 1.91 & 0.93 \\
\hline G-100-N1 & 0.96 & 537 & 3.36 & 3.23 & 1.04 \\
\hline G-100-N2 & 0.97 & 537 & 3.34 & 3.76 & 0.89 \\
\hline G-100-N3 & 0.97 & 537 & 3.19 & 3.24 & 0.98 \\
\hline G-120-N1 & 0.99 & 546 & 4.18 & 4.95 & 0.84 \\
\hline G-120-N2 & 0.98 & 546 & 4.19 & 5.00 & 0.84 \\
\hline G-120-N3 & 0.98 & 546 & 4.17 & 5.05 & 0.83 \\
\hline G-120-N4 & 0.98 & 546 & 4.14 & 4.67 & 0.89 \\
\hline G-150-N1 & 0.98 & 516 & 4.53 & 5.24 & 0.86 \\
\hline G-150-N2 & 0.98 & 516 & 4.63 & 4.91 & 0.94 \\
\hline G-150-N3 & 0.99 & 516 & 4.65 & 4.93 & 0.94 \\
\hline Mean & & & & & 0.91 \\
\hline $\mathrm{COV}$ & & & & & 0.06 \\
\hline
\end{tabular}


Table 6: Moment capacity obtained from parametric study

\begin{tabular}{|c|c|c|c|c|c|c|}
\hline Specimen & $\begin{array}{c}\text { Thickness } \\
\text { (t) } \\
(\mathrm{mm})\end{array}$ & $\begin{array}{l}\text { Area } \\
\text { (A) } \\
\mathrm{cm}^{2}\end{array}$ & $\begin{array}{l}\text { Moment } \\
\text { of inertia } \\
\text { (I) } \\
\mathrm{cm}^{4}\end{array}$ & $\begin{array}{c}\text { Yield } \\
\text { strength } \\
\left(\sigma_{\mathrm{y}}\right) \\
\left(\mathrm{N} / \mathrm{mm}^{2}\right)\end{array}$ & $\begin{array}{c}\text { Moment capacity } \\
\text { obtained from FEA } \\
\left(\mathrm{M}_{\mathrm{u}}^{\mathrm{FEA}}\right) \\
\mathrm{kNm}\end{array}$ & $\begin{array}{l}\mathrm{M}_{\mathrm{u}}^{\mathrm{FEA} /} \\
\mathrm{I} \\
\mathrm{kN} / \mathrm{cm}\end{array}$ \\
\hline U-61-M390-T1.0 & 1 & 2.25 & 11.21 & 390 & 1.29 & 11.51 \\
\hline U-61-M390-T1.2 & 1.2 & 2.70 & 13.45 & 390 & 1.6 & 11.90 \\
\hline U-61- M390-T1.4 & 1.4 & 3.15 & 15.70 & 390 & 1.99 & 12.68 \\
\hline U-61- M390-T1.6 & 1.6 & 3.60 & 17.94 & 390 & 2.38 & 13.27 \\
\hline U-61-M450-T1.0 & 1 & 2.25 & 11.21 & 450 & 1.39 & 12.40 \\
\hline U-61-M450-T1.2 & 1.2 & 2.70 & 13.45 & 450 & 1.74 & 12.94 \\
\hline U-61- M450-T1.4 & 1.4 & 3.15 & 15.70 & 450 & 2.19 & 13.95 \\
\hline U-61- M450-T1.6 & 1.6 & 3.60 & 17.94 & 450 & 2.64 & 14.72 \\
\hline U-100-M390-T1.0 & 1 & 3.06 & 39.82 & 390 & 2.13 & 5.35 \\
\hline U-100-M390-T1.2 & 1.2 & 3.67 & 47.79 & 390 & 3.06 & 6.40 \\
\hline U-100- M390-T1.4 & 1.4 & 4.29 & 55.75 & 390 & 3.88 & 6.96 \\
\hline U-100- M390-T1.6 & 1.6 & 4.90 & 63.72 & 390 & 4.73 & 7.42 \\
\hline U-100-M450-T1.0 & 1 & 3.06 & 39.82 & 450 & 2.25 & 5.65 \\
\hline U-100-M450-T1.2 & 1.2 & 3.67 & 47.79 & 450 & 3.28 & 6.86 \\
\hline U-100- M450-T1.4 & 1.4 & 4.29 & 55.75 & 450 & 4.2 & 7.53 \\
\hline U-100- M450-T1.6 & 1.6 & 4.90 & 63.72 & 450 & 5.16 & 8.10 \\
\hline G-61-M390-T1.0 & 1 & 2.25 & 11.21 & 390 & 1.42 & 12.67 \\
\hline G-61-M390-T1.2 & 12 & 2.70 & 13.45 & 390 & 1.8 & 13.38 \\
\hline G-61- M390-T1.4 & 1.4 & 3.15 & 15.70 & 390 & 2.2 & 14.01 \\
\hline G-61- M390-T1.6 & 1.6 & 3.60 & 17.94 & 390 & 2.68 & 14.94 \\
\hline G-61-M450-T1.0 & 1 & 2.25 & 11.21 & 450 & 1.7 & 15.17 \\
\hline G-61-M450-T1.2 & 1.2 & 2.70 & 13.45 & 450 & 2.11 & 15.69 \\
\hline G-61- M450-T1.4 & 1.4 & 3.15 & 15.70 & 450 & 2.58 & 16.43 \\
\hline G-61- M450-T1.6 & 1.6 & 3.60 & 17.94 & 450 & 3.03 & 16.89 \\
\hline G-100-M390-T1.0 & 1 & 3.06 & 39.82 & 390 & 3.31 & 8.31 \\
\hline G-100-M390-T1.2 & 1.2 & 3.67 & 47.79 & 390 & 4.1 & 8.58 \\
\hline G-100- M390-T1.4 & 1.4 & 4.29 & 55.75 & 390 & 5.07 & 9.09 \\
\hline G-100- M390-T1.6 & 1.6 & 4.90 & 63.72 & 390 & 6.03 & 9.46 \\
\hline G-100-M450-T1.0 & 1 & 3.06 & 39.82 & 450 & 3.75 & 9.42 \\
\hline G-100-M450-T1.2 & 1.2 & 3.67 & 47.79 & 450 & 4.46 & 9.33 \\
\hline G-100- M450-T1.4 & 1.4 & 4.29 & 55.75 & 450 & 5.4 & 9.69 \\
\hline G-100- M450-T1.6 & 1.6 & 4.90 & 63.72 & 450 & 6.35 & 9.97 \\
\hline
\end{tabular}


Table 7: Moment capacity obtained from load tables for zed purlins

\begin{tabular}{|c|c|c|c|c|c|c|}
\hline Specimen & $\begin{array}{l}\text { Thickness } \\
\begin{array}{c}(\mathrm{t}) \\
(\mathrm{mm})\end{array}\end{array}$ & $\begin{array}{l}\text { Area } \\
\text { (A) } \\
\mathrm{cm}^{2}\end{array}$ & $\begin{array}{c}\text { Moment } \\
\text { of inertia } \\
\text { (I) } \\
\mathrm{cm}^{4} \\
\end{array}$ & $\begin{array}{c}\text { Yield } \\
\text { strength } \\
\left(\sigma_{\mathrm{y}}\right) \\
\left(\mathrm{N} / \mathrm{mm}^{2}\right) \\
\end{array}$ & $\begin{array}{l}\text { Moment capacity } \\
\text { obtained from load } \\
\text { table }\left(\mathrm{M}_{\mathrm{u}}^{\text {Load table }}\right) \\
\mathrm{kNm}\end{array}$ & $\mathrm{M}_{\mathrm{u}}^{\mathrm{FEA}} / \mathrm{I}$ \\
\hline U-Z140-M390-T1.4 & 1.4 & 3.81 & 116.80 & 390 & 4.57 & 3.91 \\
\hline U-Z140-M390-T1.5 & 1.5 & 4.08 & 124.70 & 390 & 5.46 & 4.38 \\
\hline U-Z140-M390-T1.6 & 1.6 & 4.35 & 132.70 & 390 & 6.35 & 4.79 \\
\hline G-Z140-M390-T1.4 & 1.4 & 3.81 & 116.80 & 390 & 5.61 & 4.80 \\
\hline G-Z140-M390-T1.5 & 1.5 & 4.08 & 124.70 & 390 & 6.70 & 5.37 \\
\hline G-Z140-M390-T1.6 & 1.6 & 4.35 & 132.70 & 390 & 7.79 & 5.87 \\
\hline
\end{tabular}




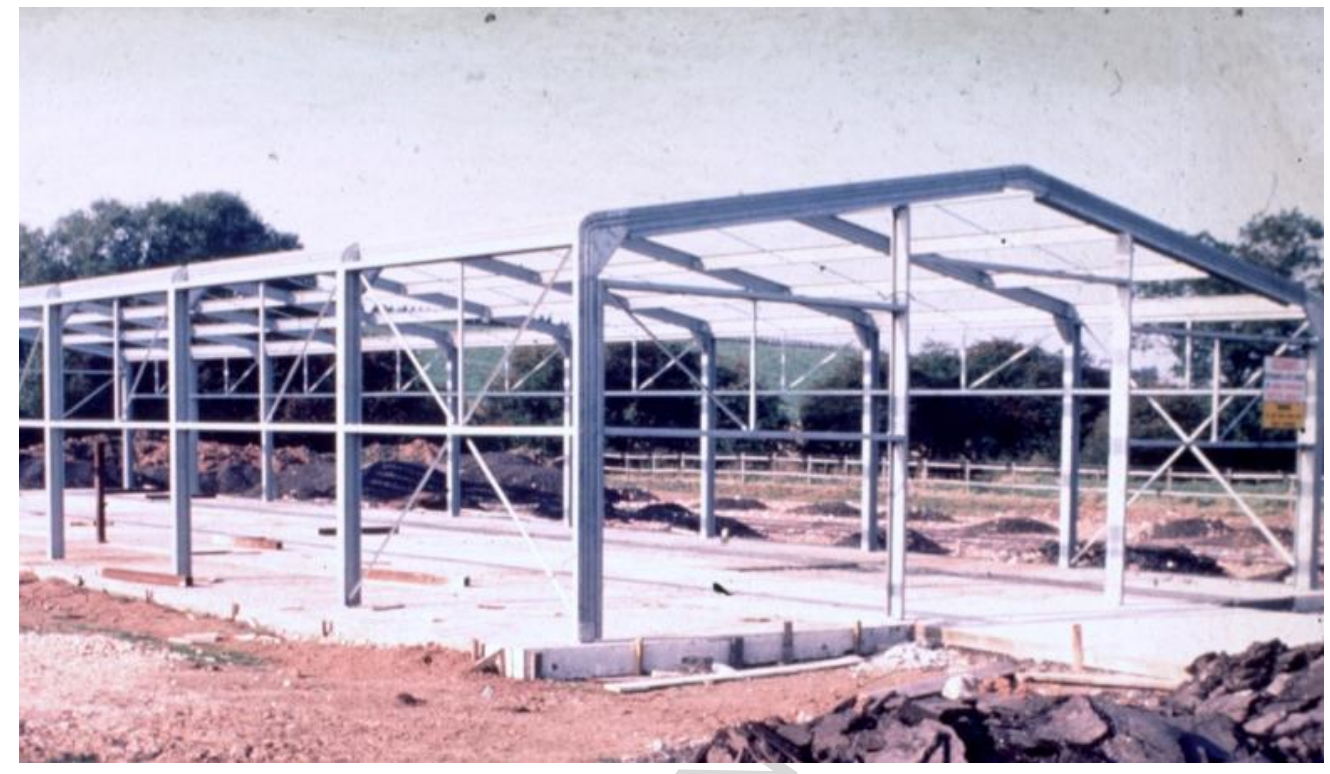

Fig. 1: Cold-formed steel portal framing system
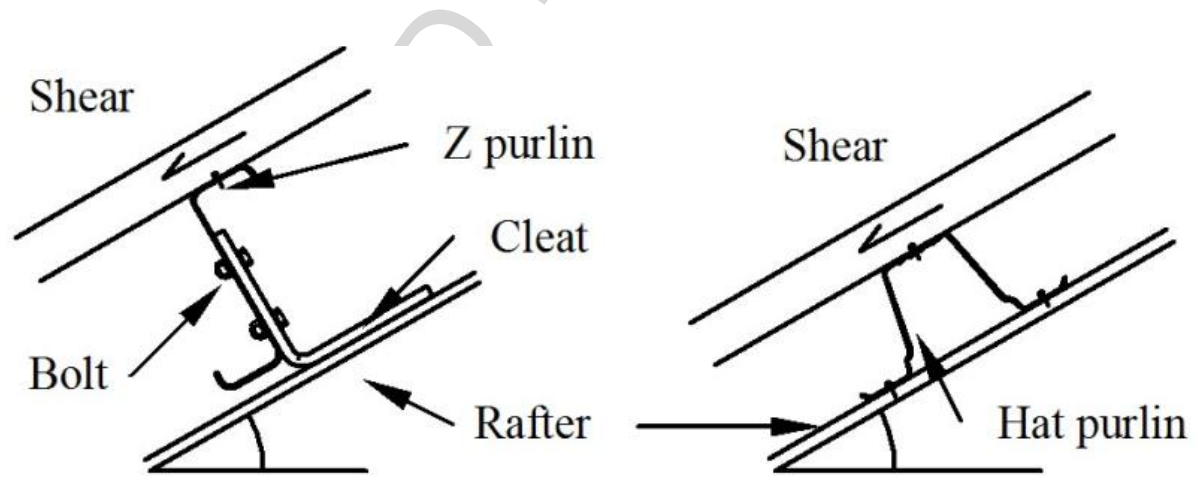

a) Typical Z purlin connection

b) Hat-shape purlin connection

Fig. 2: Typical Z purlin and hat-shape purlin connection 


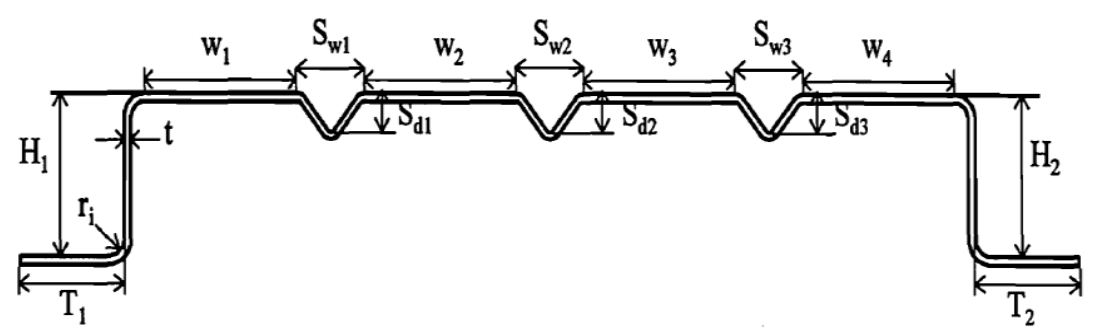

(a) Hat shaped section tested by Acharya and Schuster [4]

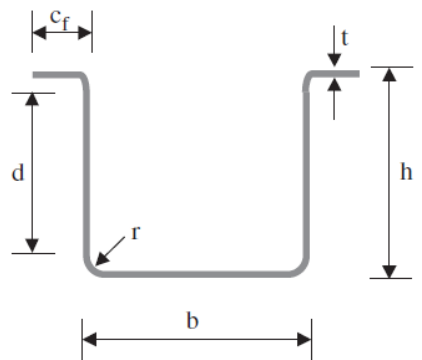

(b) Pastor and Roure un-lipped channel $[5,6]$

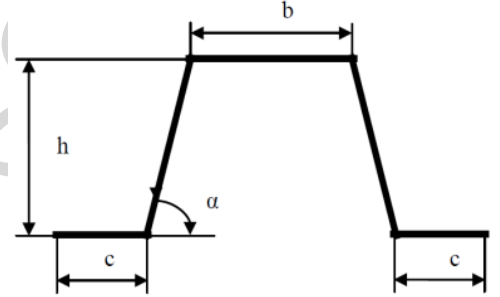

(c) Honfi hat shaped section [7]

Fig. 3: Different hat shaped sections found in the literature

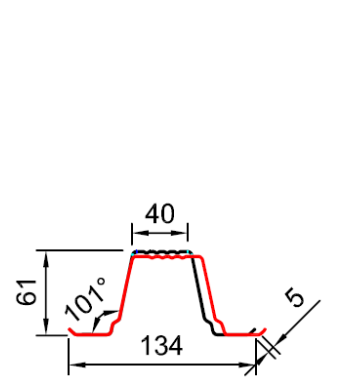

(a) Top-hat 61

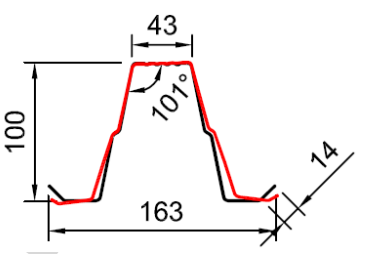

(b) Top-hat 100

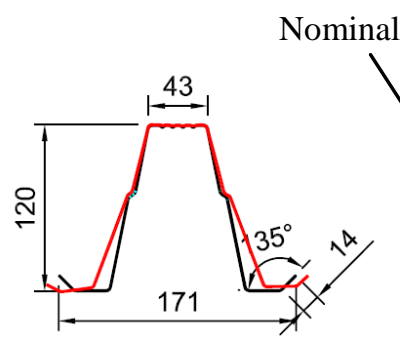

(c) Top-hat 120

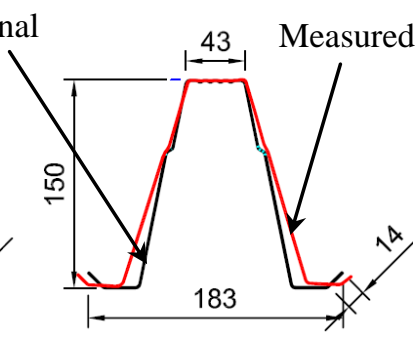

(d) Top-hat 150

Fig. 4: Nominal and measured cross-section of four types of top-hat section 


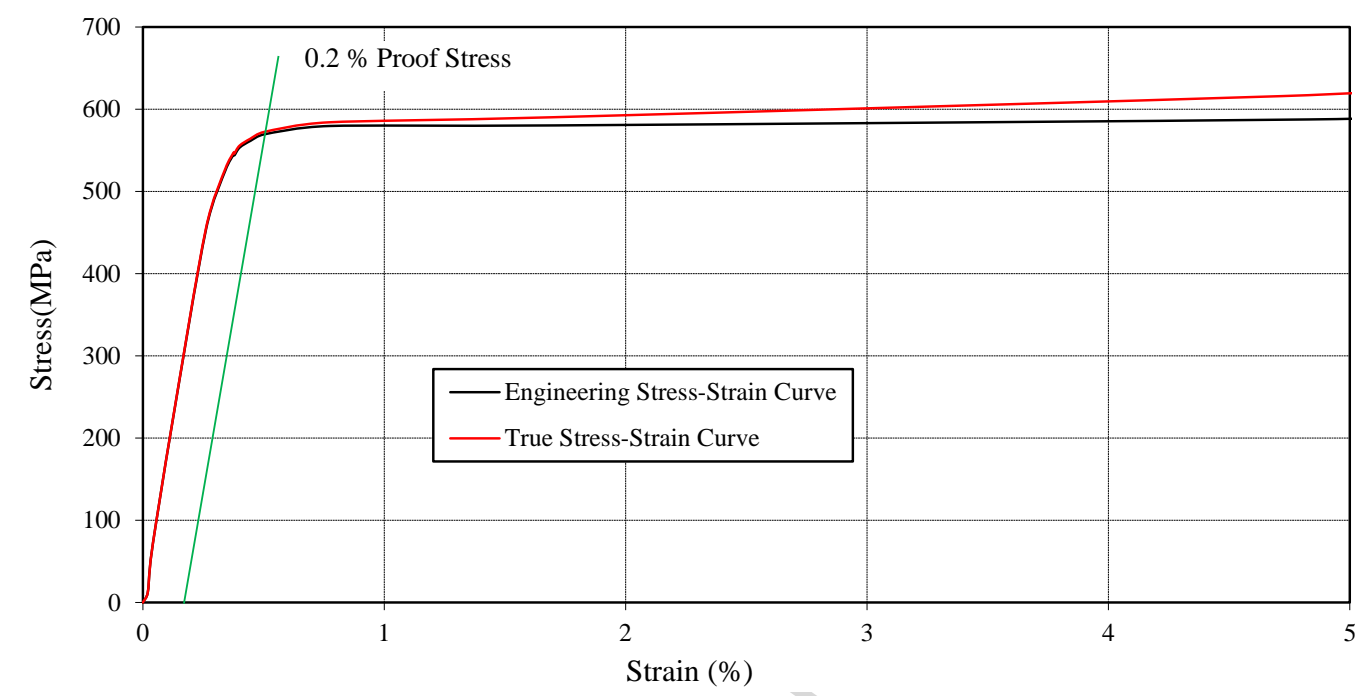

Fig. 5: Typical stress-strain curves for the web element of section U-61

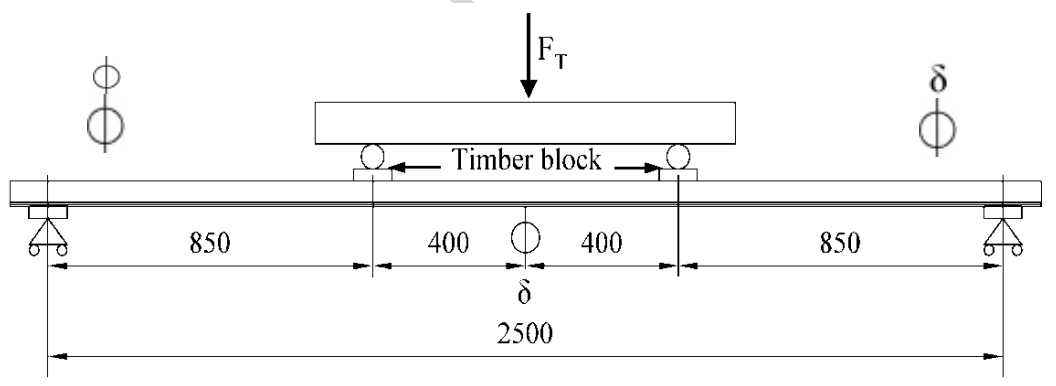

$\delta$ - displacement; $\mathrm{F}_{\mathrm{T}}$ - jacking force

(a) Schematic view of test set-up

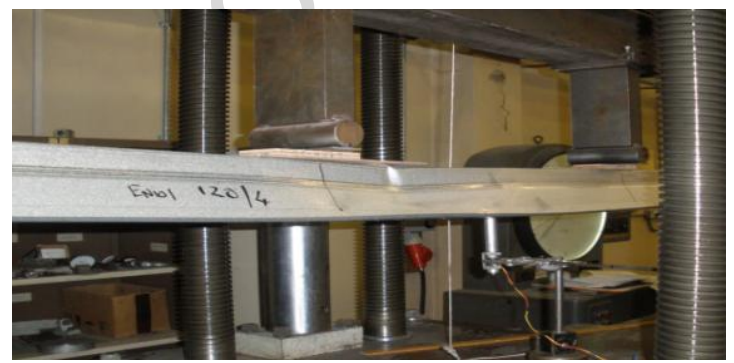

(b) Test photograph of gravity loading direction for G-120-N4 specimen

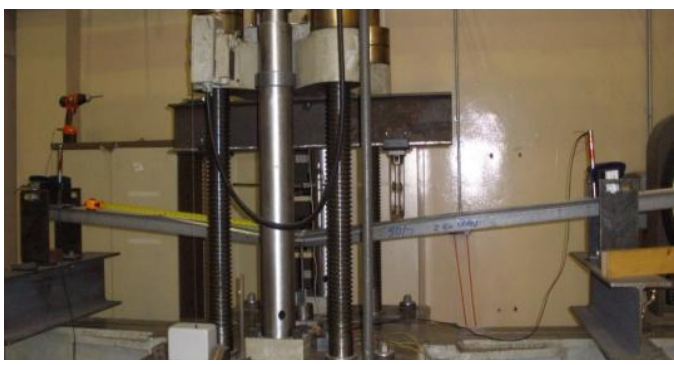

(c)Test photograph of uplift loading direction for U-61-N3 specimen

Fig. 6: Details of the top-hat test arrangement under four point bending 
Support allowing both

rotational and horizontal

movement

Shaft of $50 \mathrm{~mm} \varnothing$ roller turn

down to $25 \mathrm{~mm} \varnothing$ to locate

into 26x46mm kidney shaped

hole in support

Indicate $50 \mathrm{~mm} \emptyset$ roller with flat

Flat on roller
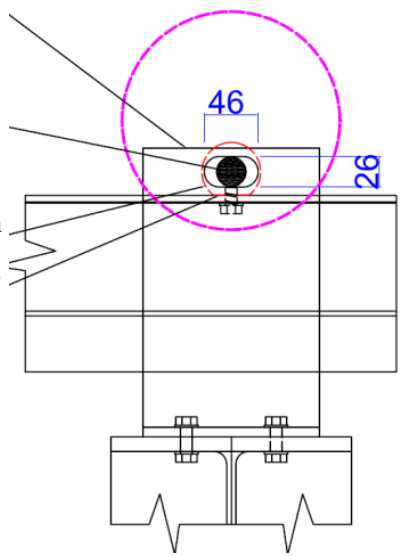

(a) Schematic view of test rig supports

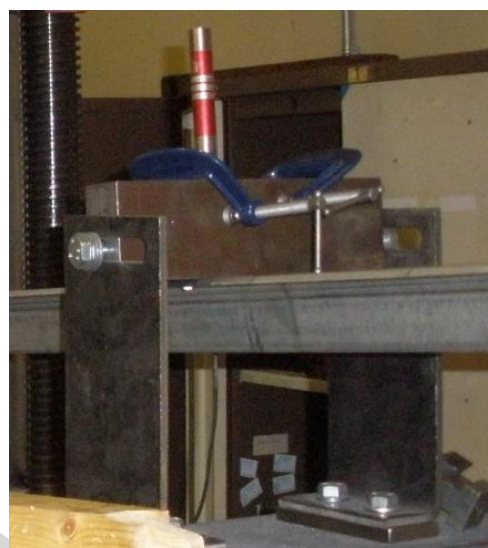

(b) Photograph of test rig supports

Fig. 7: Details of the test-rig support

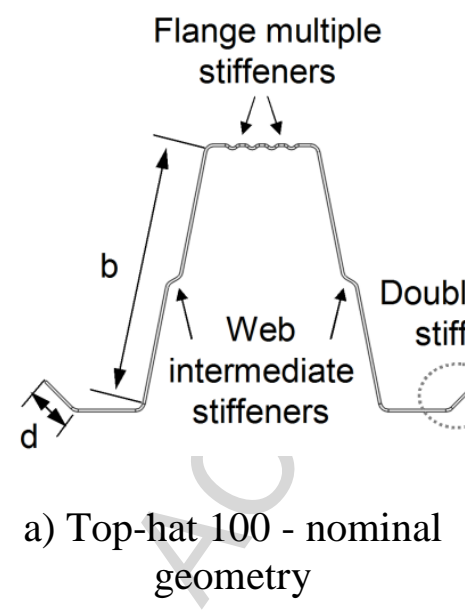

Fig. 8: Details of EC3 analysis
Compression

$d / b<0.1$ thus $d=0$

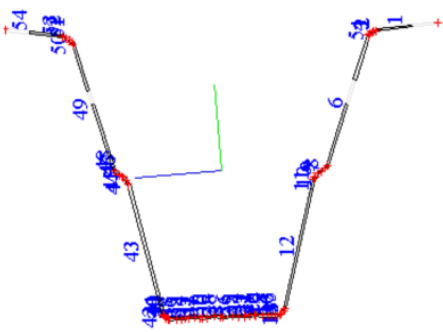

c) U-100-N3 - measured geometry including effective cross section b) G-100-N2 - measured
geometry including
effective cross section 


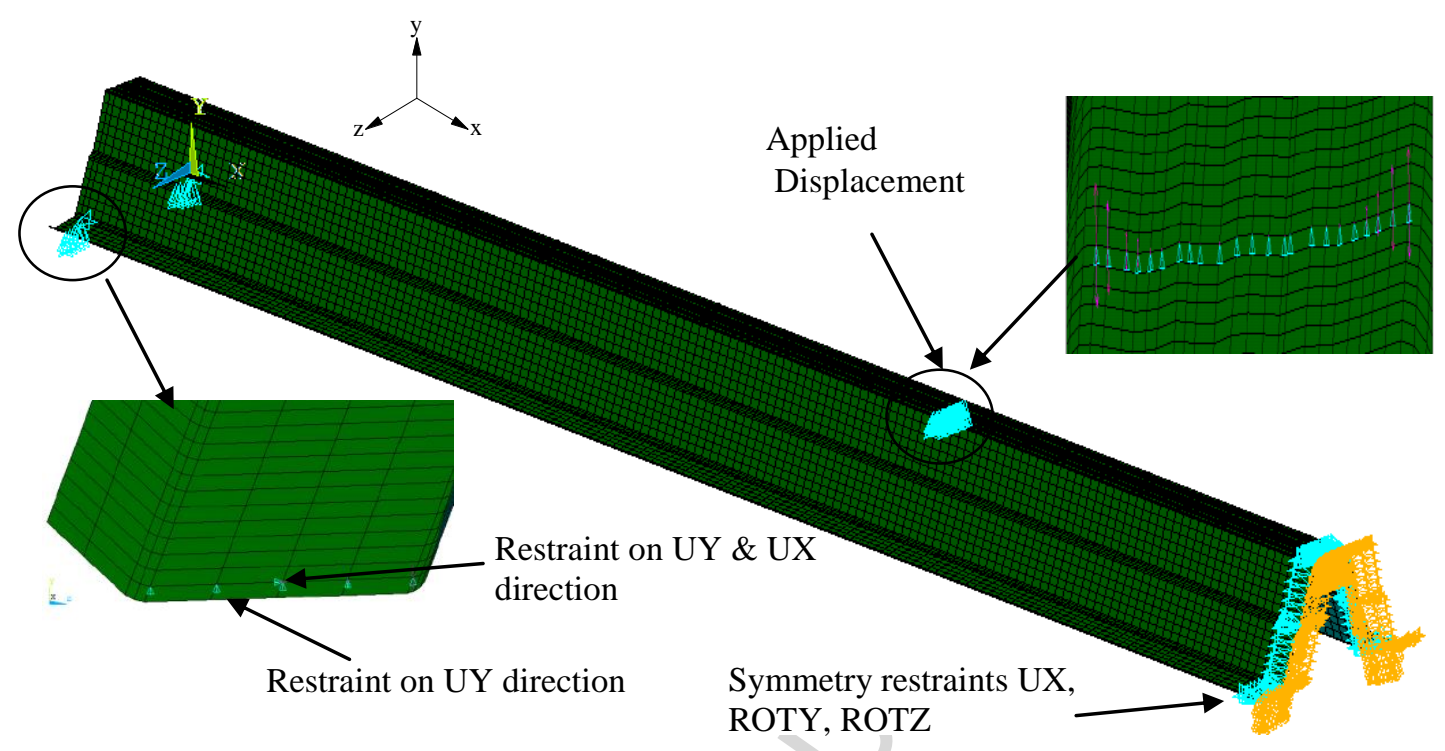

Fig. 9: Details of finite element idealization 


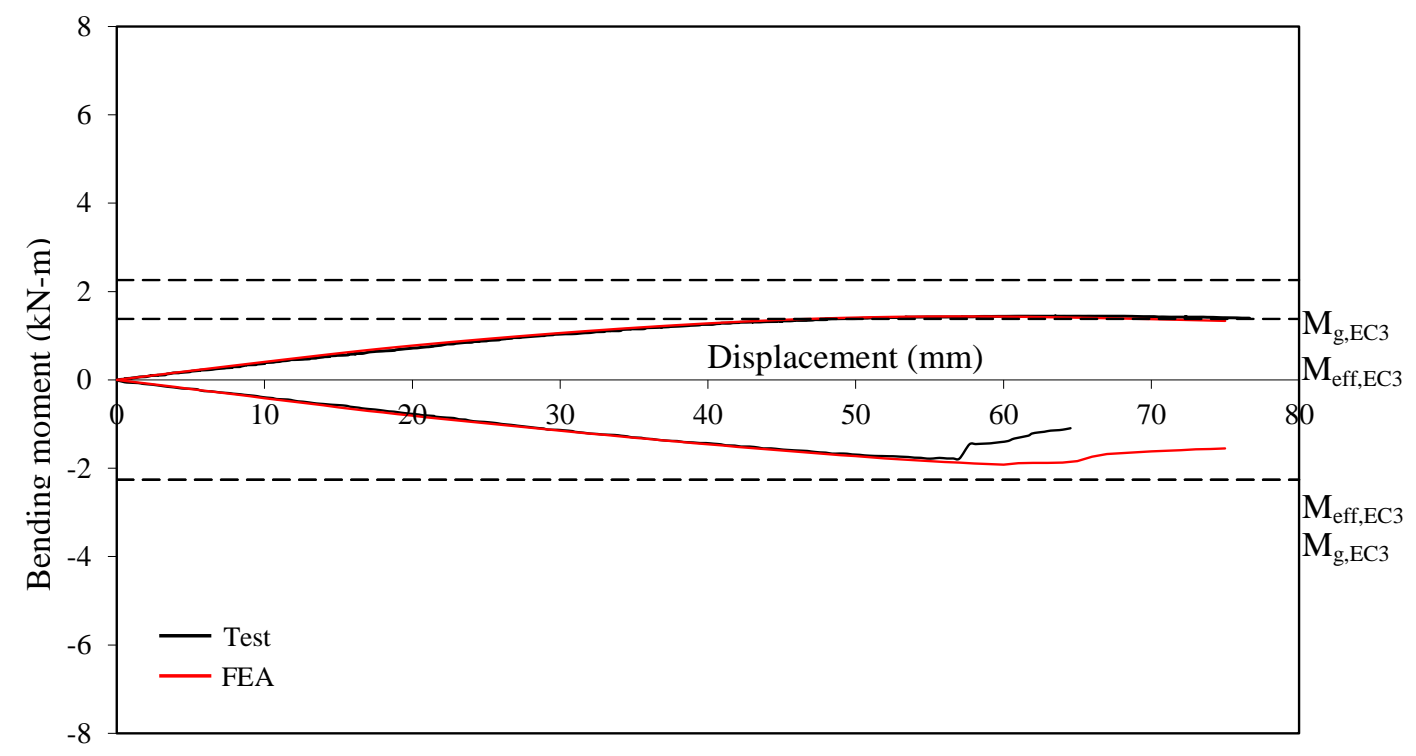

(a) U-61-N3 and G-61-N1 specimens

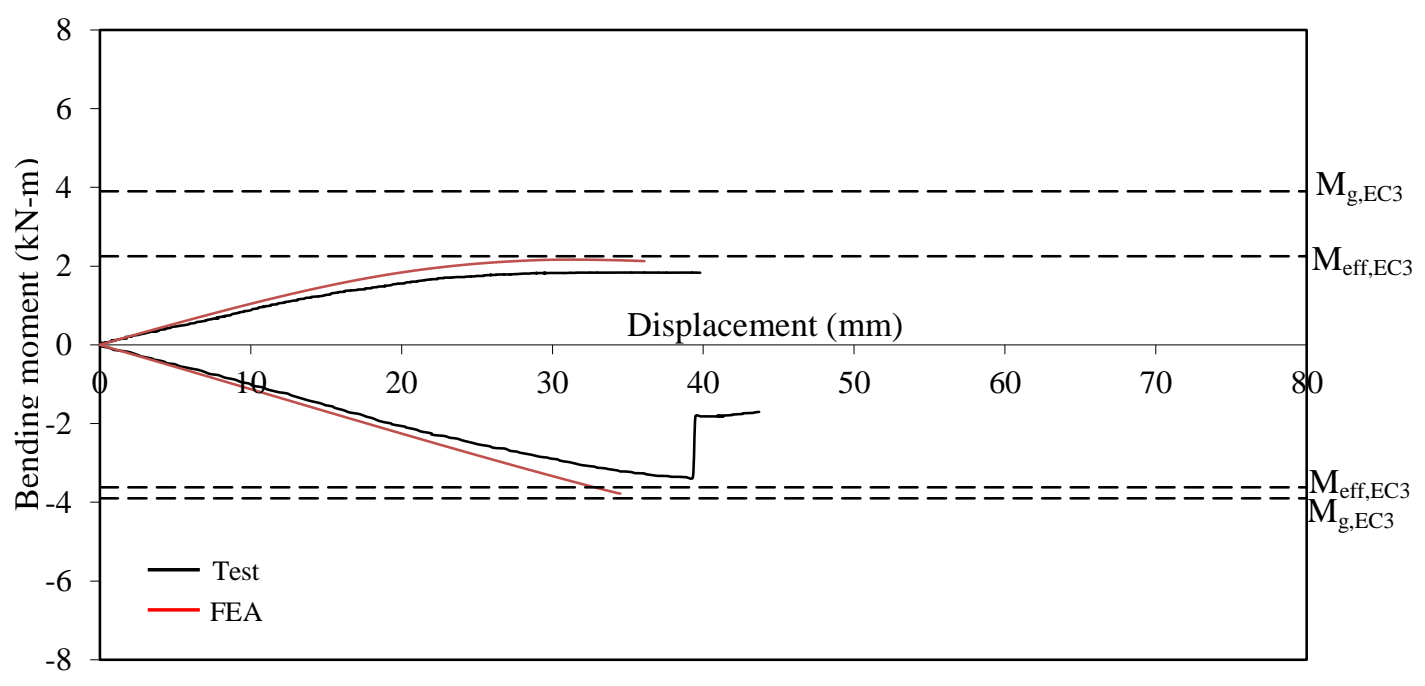

(b) U-100-N3 and G-100-N2 specimens 


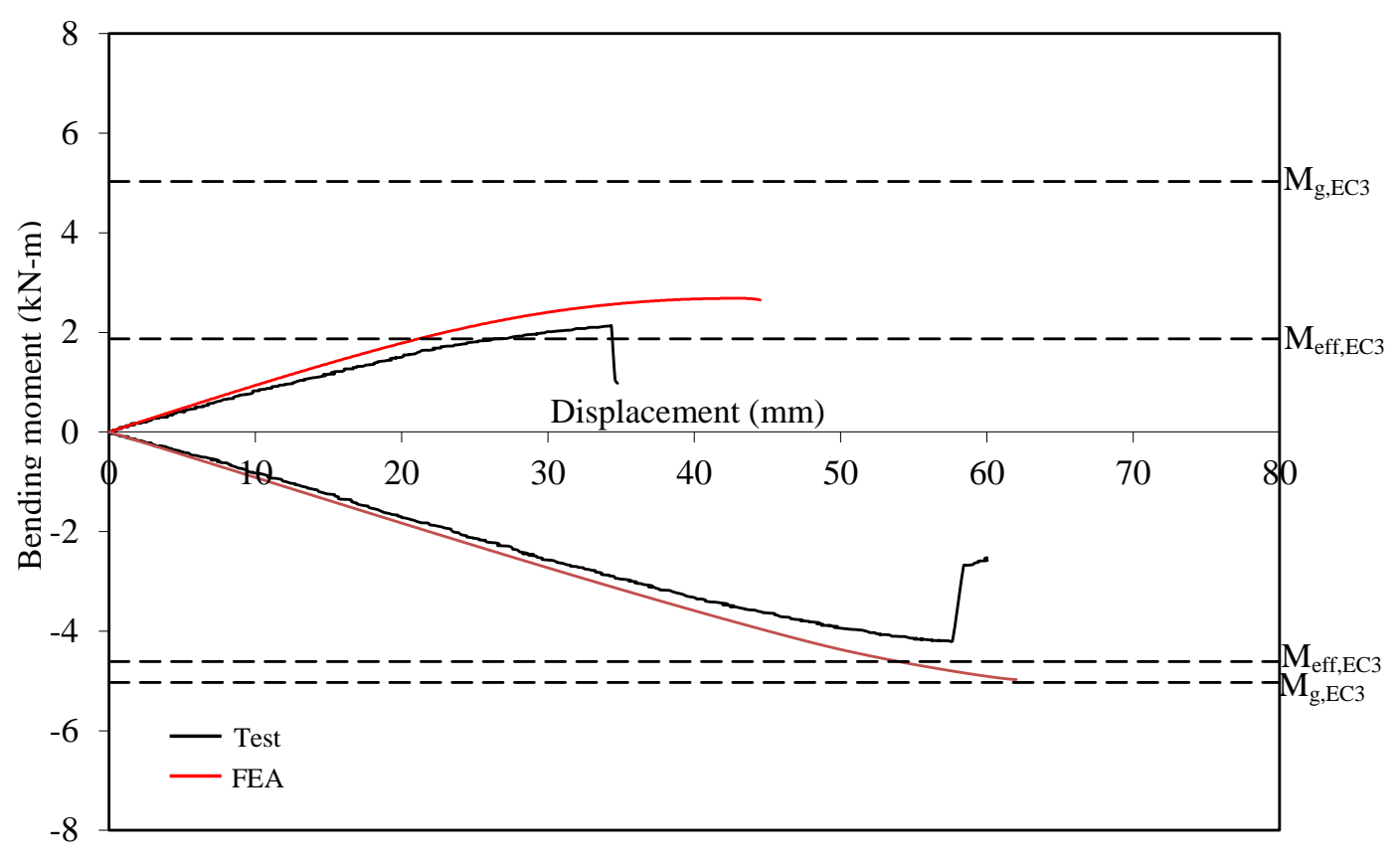

(c) U-120-N2 and G-120-N2 specimens

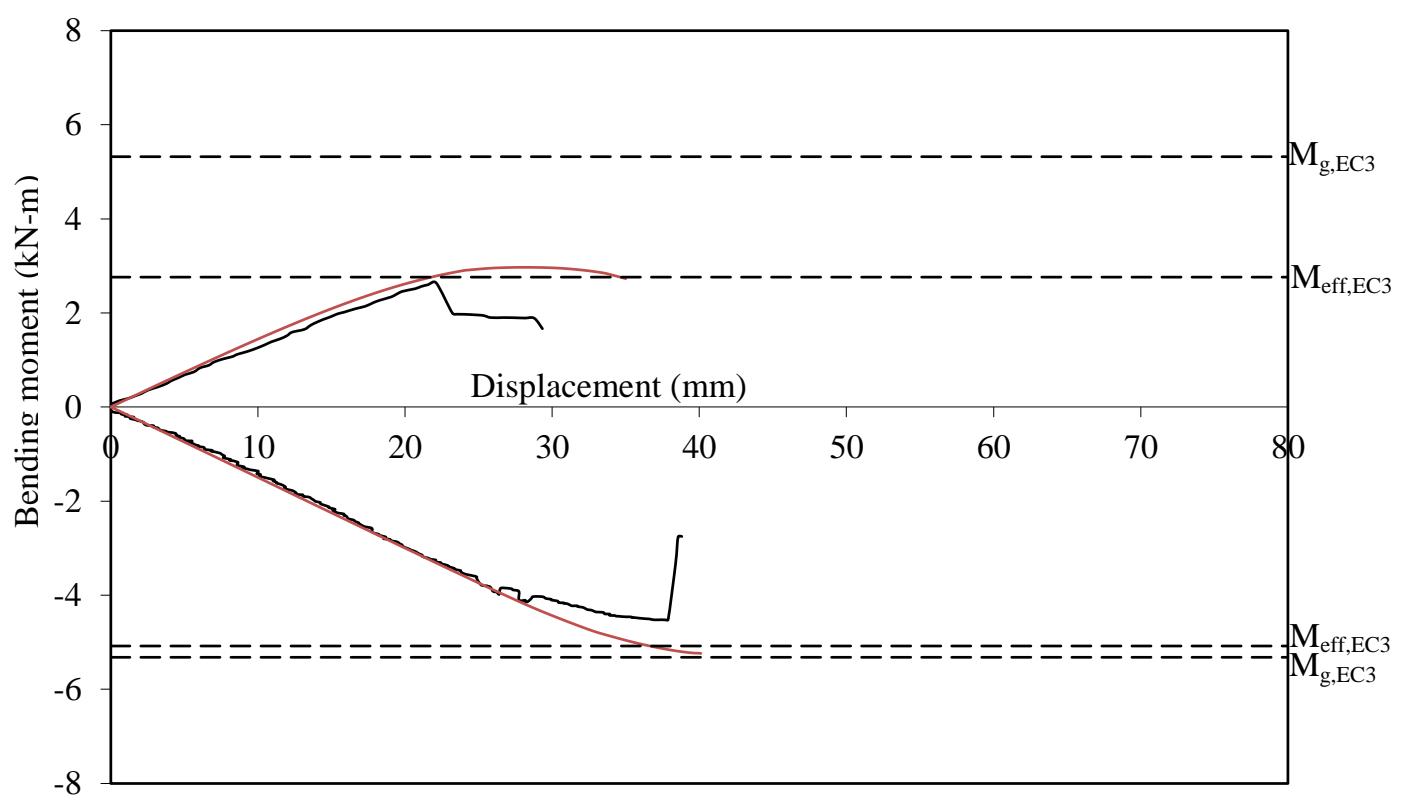

(d) U-150-N3 and G-150-N2 specimens

Fig. 10: Variation of bending moment against central deflection 

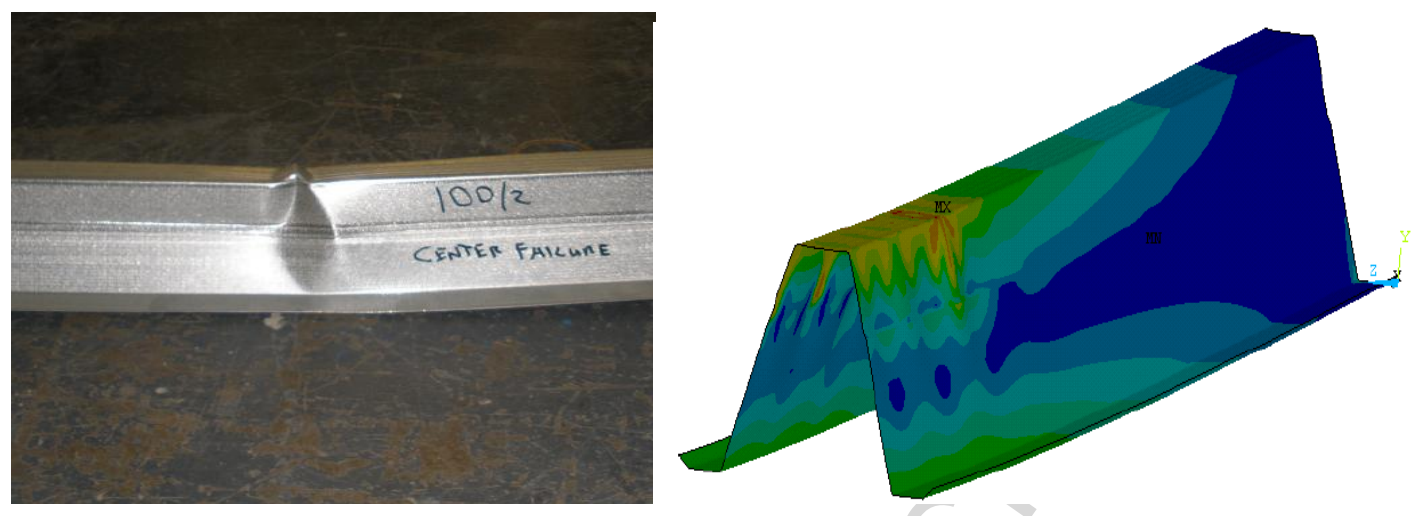

Fig. 11: Comparison of deformed shape for gravity loading direction
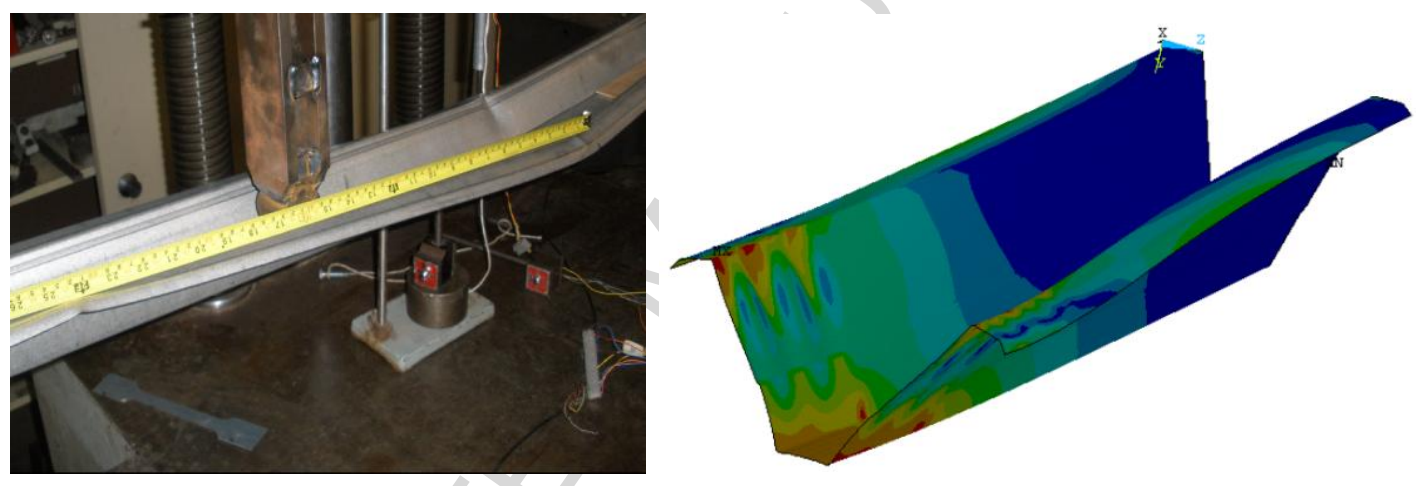

Fig. 12: Comparison of deformed shape for uplift loading direction

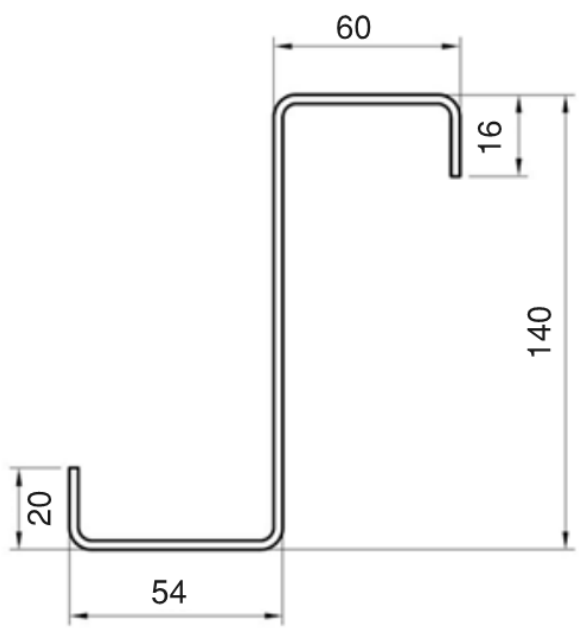

Fig. 13: Nominal dimensions of Z140 section 


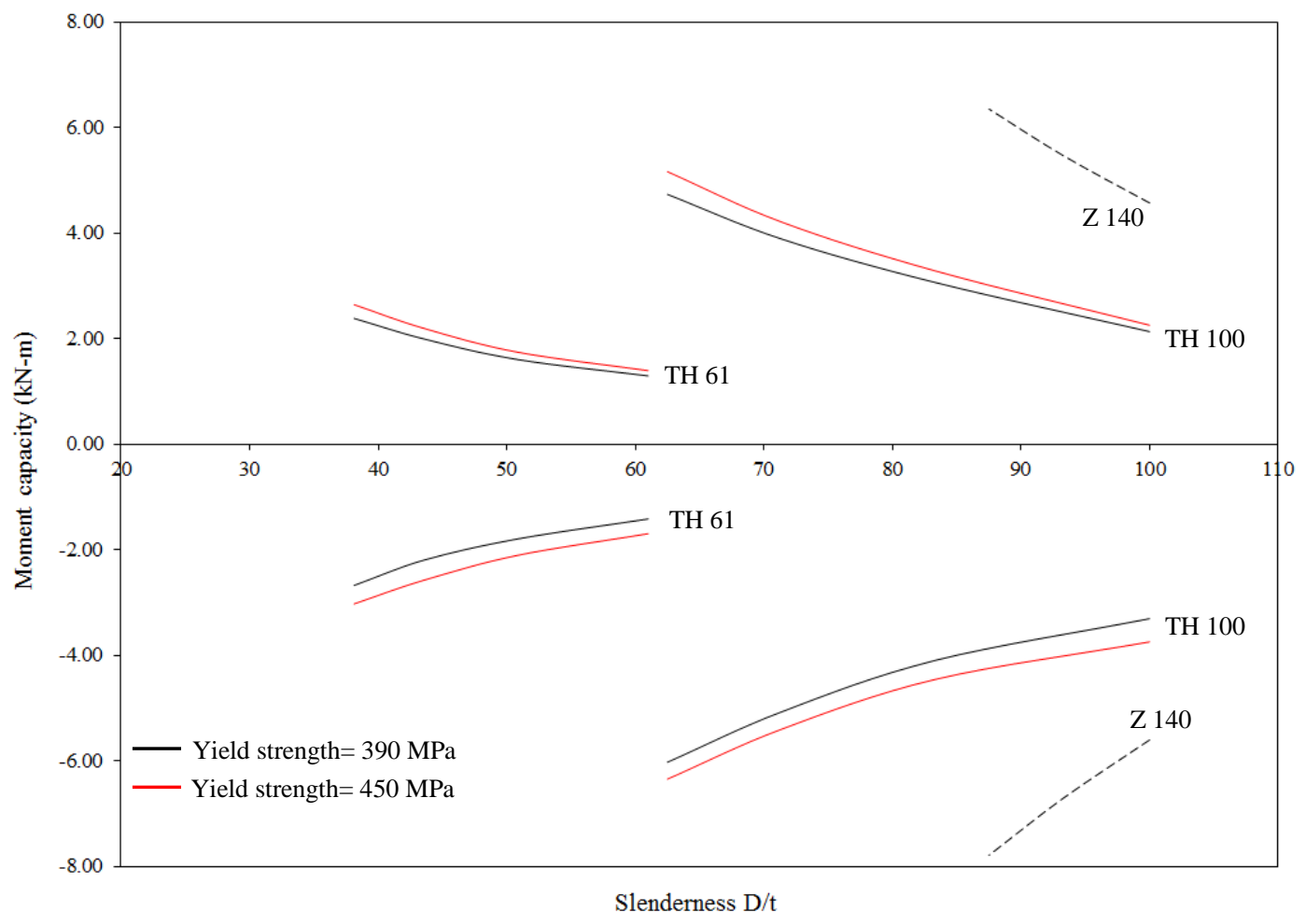

Fig. 14: Effects of section slenderness and material grade on bending moment capacity.

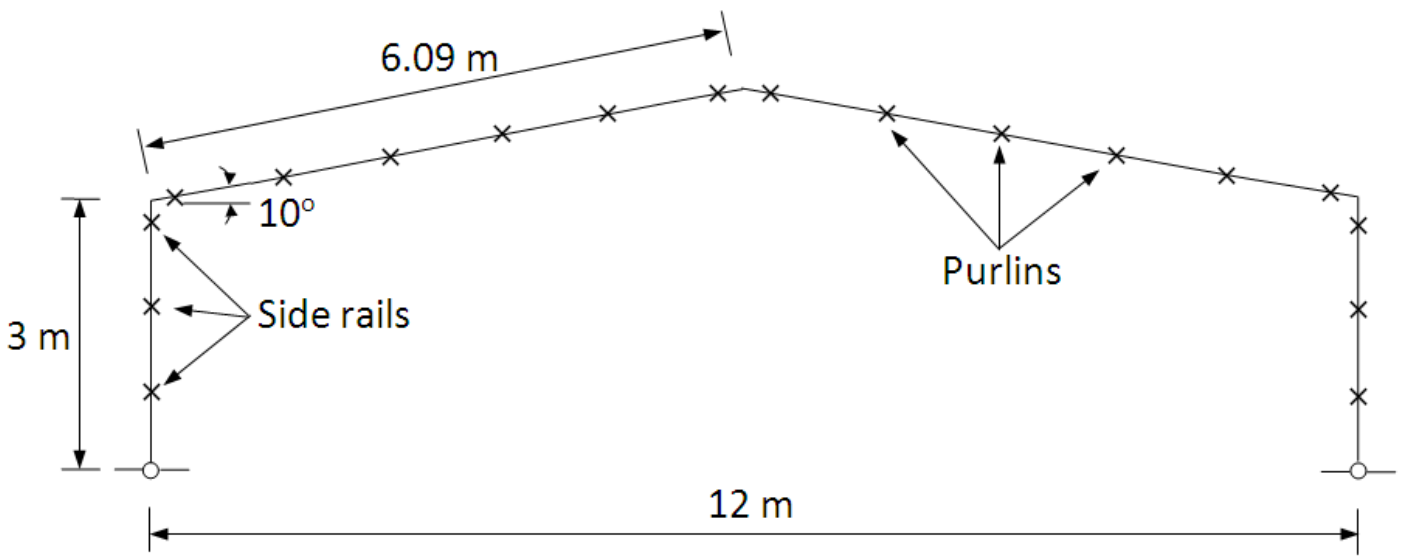

Fig. 15: Geometry of portal frame building 


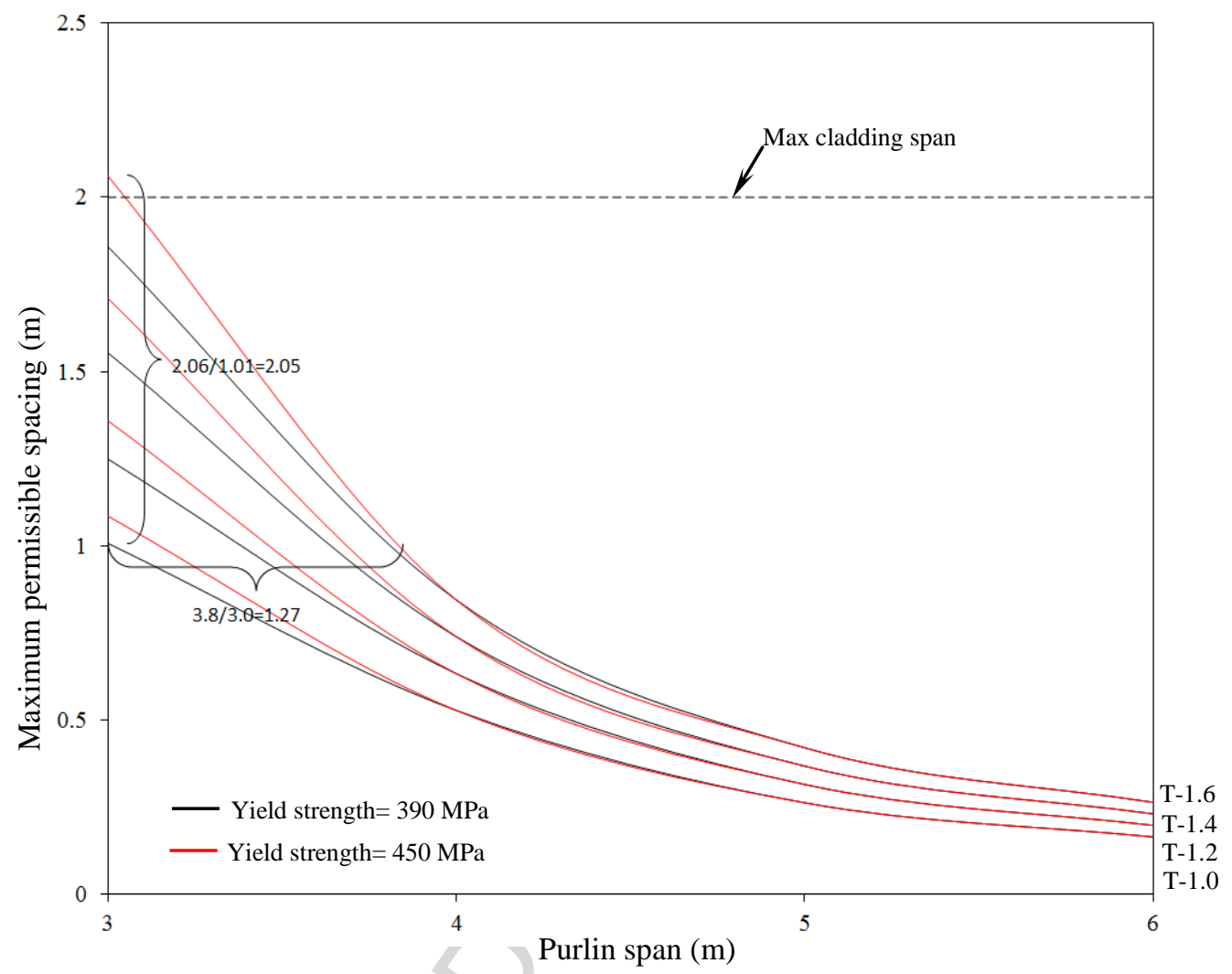

(a) Top-hat 61 purlin

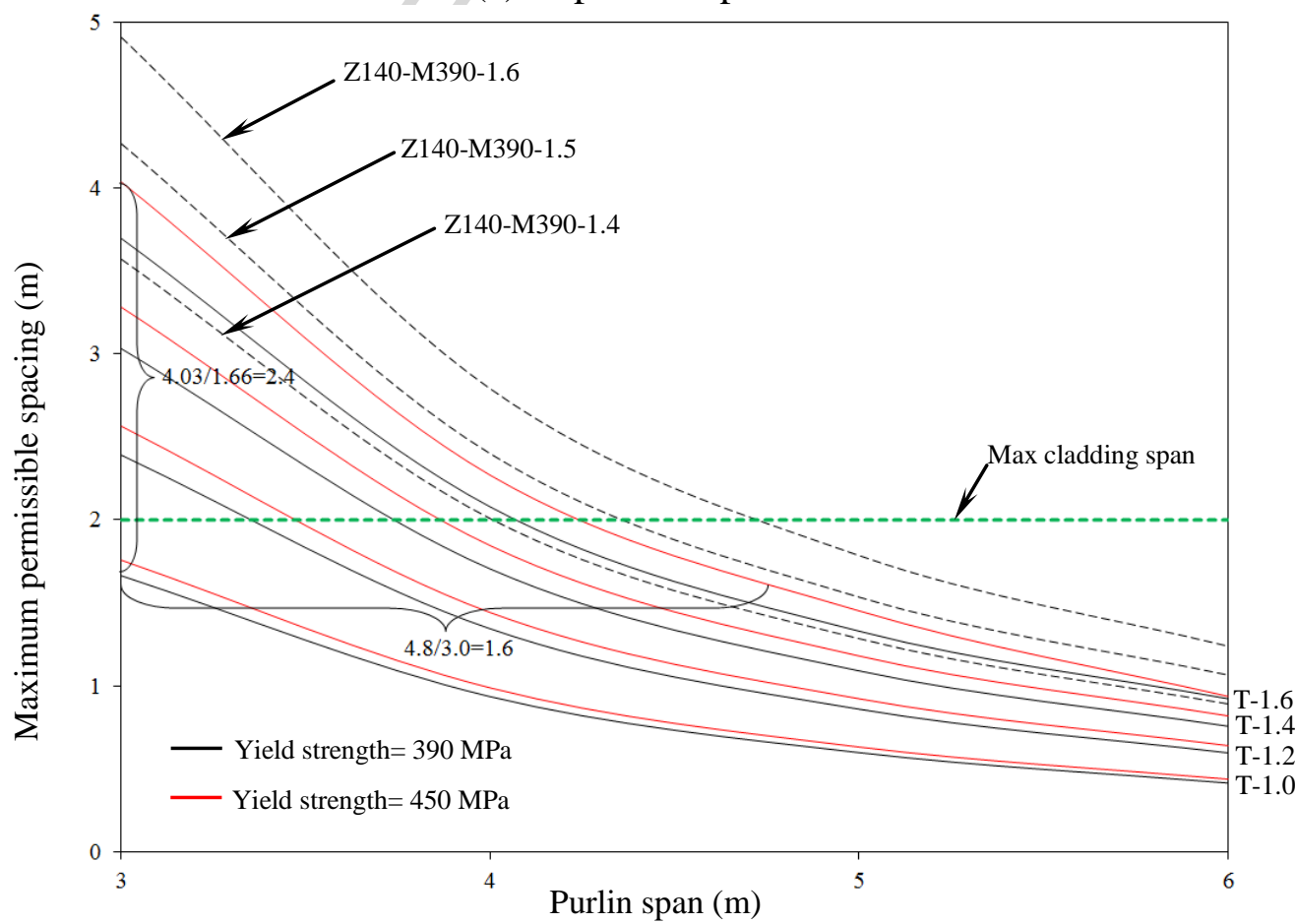

(b) Top-hat 100 purlins

Fig. 16: Variation of maximum permissible spacing against span 


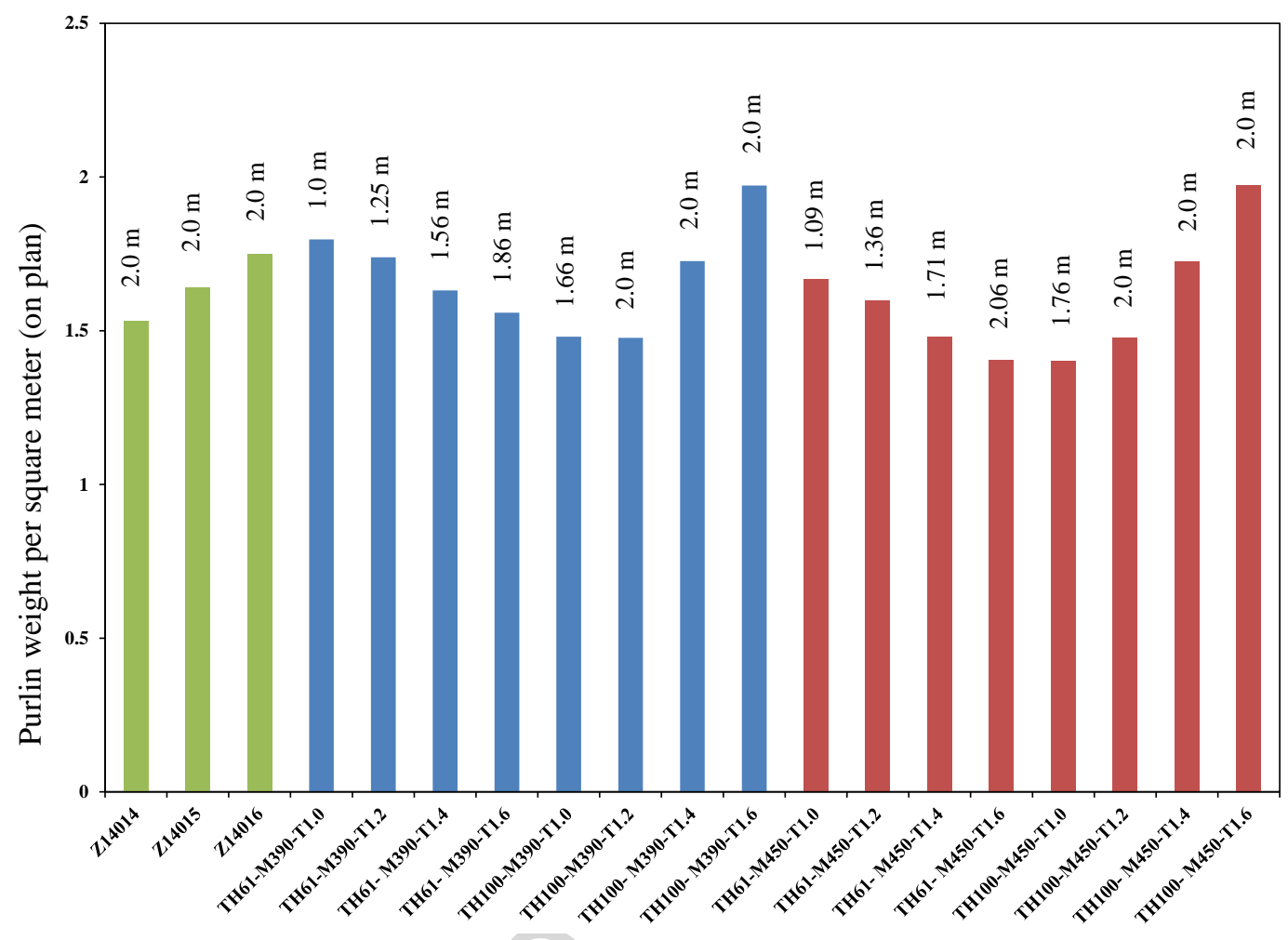

(a) $3 \mathrm{~m}$ span

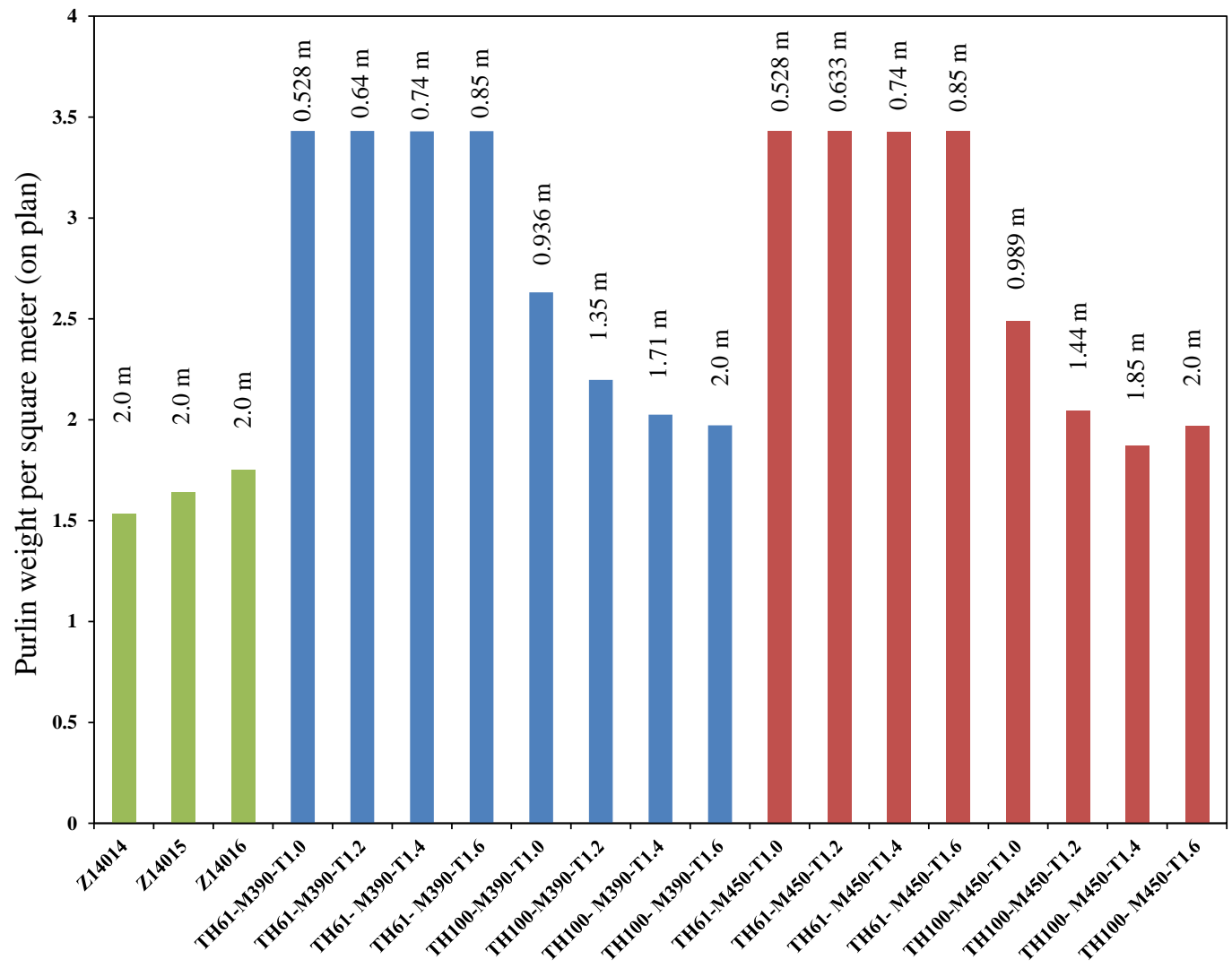

(b) $4 \mathrm{~m}$ span 


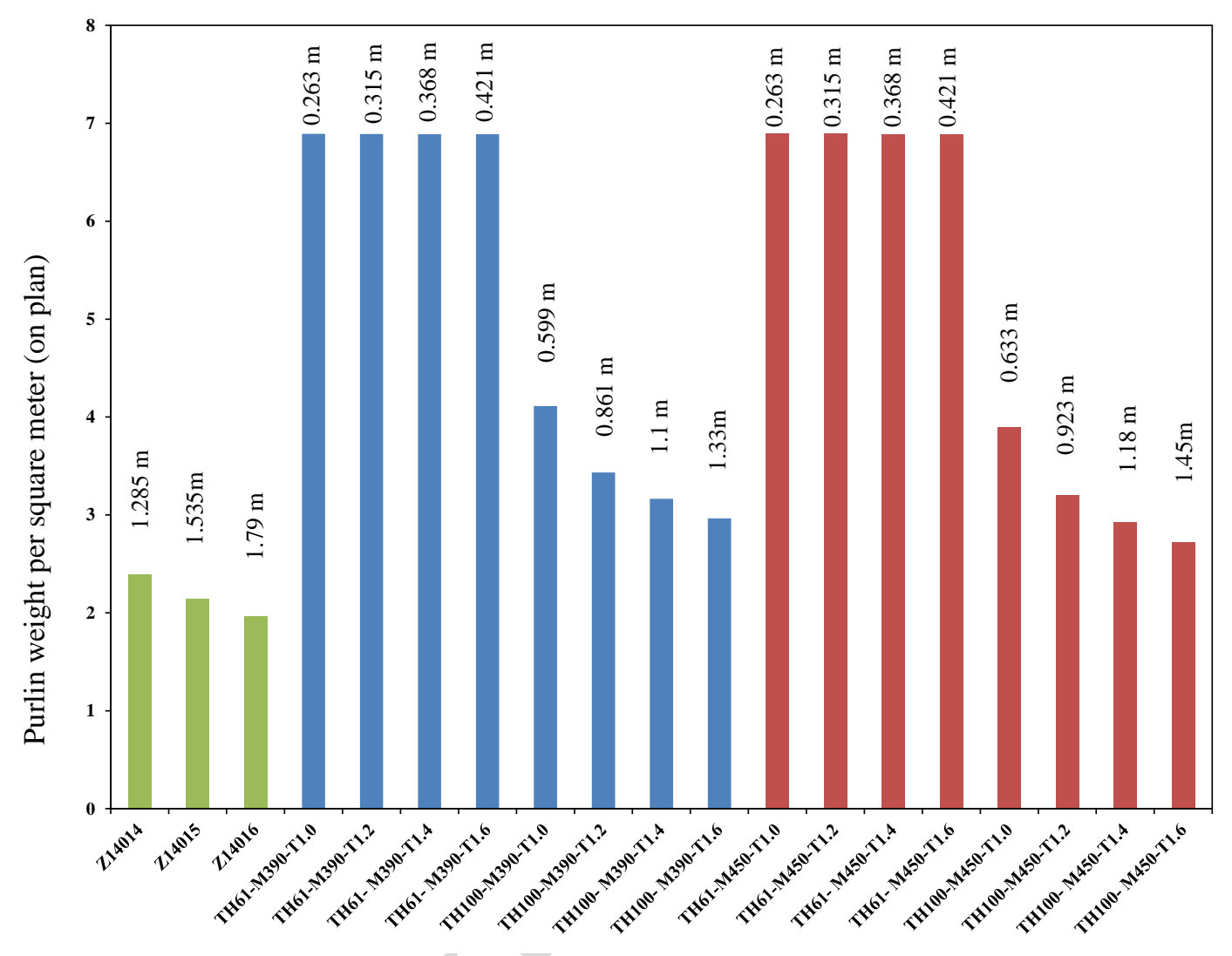

(c) $5 \mathrm{~m}$ span

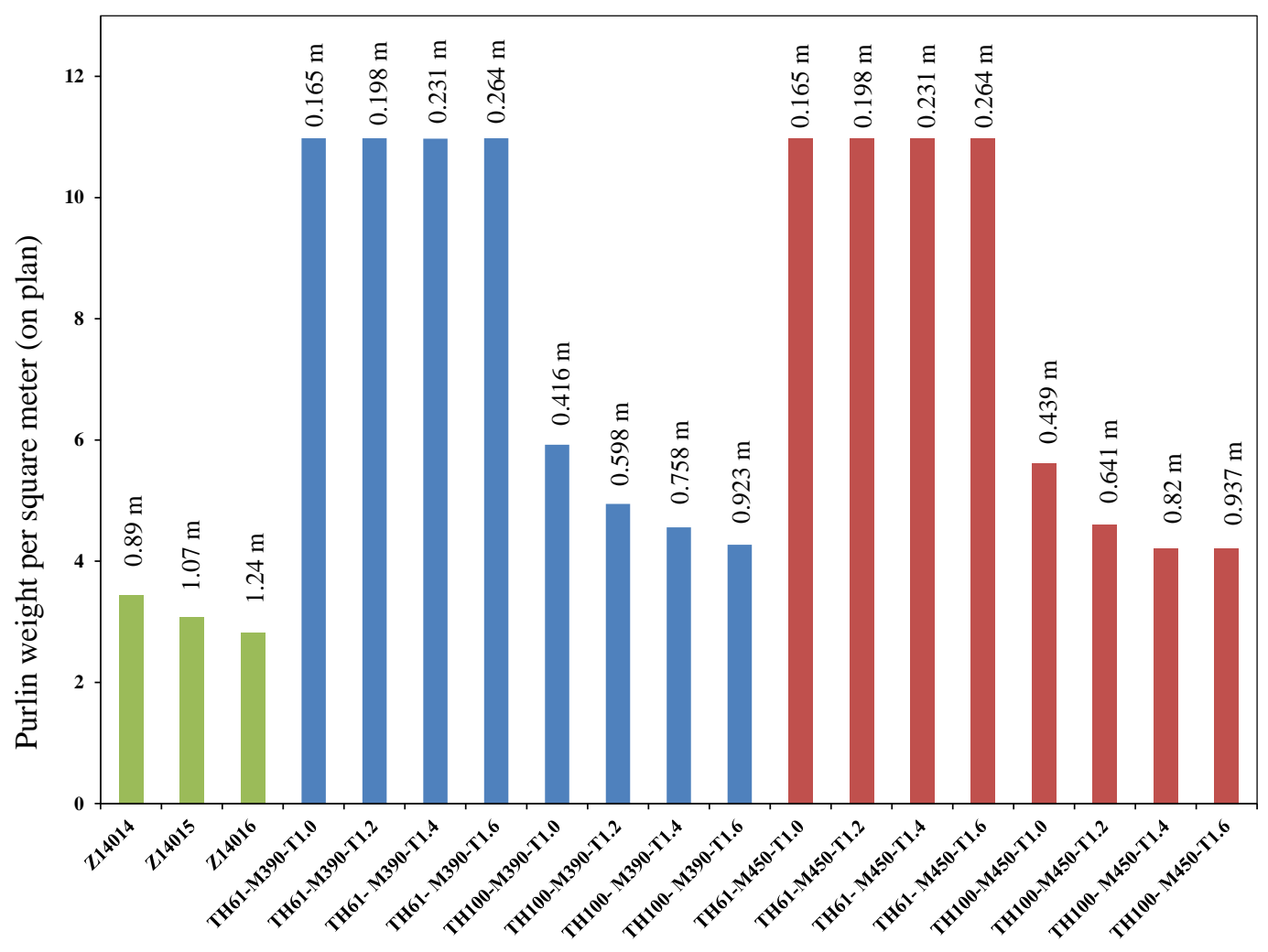

(d) $6 \mathrm{~m}$ span

Fig. 17: Purlin weight per square meter (on plan) 


\section{$\underline{\text { Research Highlights }}$}

Viability of using top-hat sections for purlins in cold-formed steel portal frames.

Experimental investigation of cold formed top-hat sections subjected to four point bending.

Non-linear finite element models have been developed and verified against the experimental test results.

> Parametric studies were carried out to study to investigate the effect of different thicknesses and steel grades.

Design recommendations are provided in the form of charts. 